Florida International University FIU Digital Commons

$11-4-2008$

\title{
More than roses : the journey toward selfhood in Beauty, Rose Daughter, and Beast
}

Gricel Dominguez

Florida International University

DOI: $10.25148 /$ etd.FI15101212

Follow this and additional works at: https://digitalcommons.fiu.edu/etd

Part of the English Language and Literature Commons

\section{Recommended Citation}

Dominguez, Gricel, "More than roses : the journey toward selfhood in Beauty, Rose Daughter, and Beast" (2008). FIU Electronic Theses and Dissertations. 3075.

https://digitalcommons.fiu.edu/etd/3075

This work is brought to you for free and open access by the University Graduate School at FIU Digital Commons. It has been accepted for inclusion in FIU Electronic Theses and Dissertations by an authorized administrator of FIU Digital Commons. For more information, please contact dcc@fiu.edu. 
FLORIDA INTERNATIONAL UNIVERSITY

Miami, Florida

MORE THAN ROSES: THE JOURNEY TOWARD SELFHOOD IN BEAUTY, ROSE DAUGHTER, AND BEAST

A thesis submitted in partial fulfillment of the

requirements for the degree of

MASTER OF ARTS

in

ENGLISH

by

Gricel Dominguez

2008 
To: Dean Kenneth Furton

College of Arts and Sciences

This thesis, written by Gricel Dominguez, and entitled More than Roses: The Journey toward Selfhood in Beauty, Rose Daughter, and Beast, having been approved in respect to style and intellectual content, is referred to you for judgment.

We have read this thesis and recommend that it be approved.

Richard A. Schwartz

Phillip L. Marcus

Maneck H. Daruwala, Major Professor

Date of Defense: November 4, 2008

The thesis of Gricel Dominguez is approved.

Dean Kenneth Furton College of Arts and Sciences

Dean George Walker University Graduate School

Florida International University, 2008 


\section{DEDICATION}

To my mom, for encouraging my love of fairy tales when I was a little girl. And because "Beauty and the Beast" is her favorite. 


\section{ACKNOWLEDGMENTS}

My deepest gratitude goes to my major professor, Dr. Maneck Daruwala whose guidance and friendship supported me through this process. Thanks to Dr. Richard Schwartz for encouraging me to take a chance (and keeping my writing in line). Thanks also to Dr. Phillip Marcus for reminding me "It's great to be here!" 


\title{
ABSTRACT OF THE THESIS
}

MORE THAN ROSES: THE JOURNEY TOWARD SELFHOOD IN BEAUTY, ROSE

\author{
DAUGHTER, AND BEAST \\ by
}

Gricel Dominguez

Florida International University, 2008

Miami, Florida

Professor Maneck H. Daruwala, Major Professor

The purpose of this study was to examine the implications of selfhood in three retellings of the "Beauty and the Beast" story-Robin McKinley's Beauty and Rose Daughter, and Donna Jo Napoli's Beast-analyzing those factors that affected each protagonist's understanding of the self, how these challenged or aided them in their journey towards self-actualization, and how a sense of personal gratification represented the true reward at the end of the ordeal.

My analysis was informed by the Jungian concept of the Self as the goal of individuation, and Joseph Campbell's model of the hero's journey. As such, I found that these retellings illustrated the hero's journey as a representation of the process of individuation and the benefits to be gained by reaching this state of wholeness. 


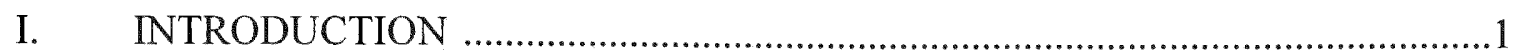

II. TO SEE ONSELF: BEAUTY'S QUEST TO FIND HER SELF IN ROBIN MCKINLEY'S BEAUTY

III. FOLLOWING IT TO ITS END: FATE, CHOICE, AND BECOMING 'SELFISH' IN ROSE DAUGHTER.

IV. "STRANGE LIFE": PRIDE, CONCEIT, AND LOSS OF IDENTITY IN DONNA JO NAPOLI'S BEAST 60

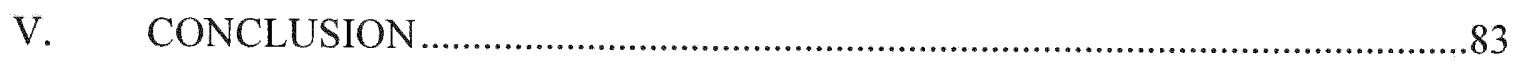

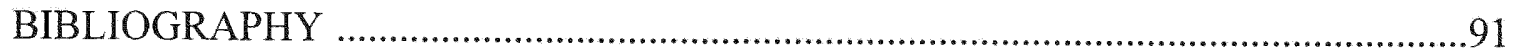




\section{Chapter I: Introduction}

\section{A Brief History of "Beauty and the Beast"}

Among the best-known fairytales, the story of "Beauty and the Beast" has appeared in numerous incarnations, popularized through film and television, located in both modern and fantastical settings, told and retold while retaining the essence of the original tale. However, the version of "Beauty and the Beast" that most have come to know did not originate in the oral tradition, though the tale shares the animal groom motif found in folktales across various cultures (Altman and De Vos 3; Hearne 13). This story was the invention of Madame Gabrielle-Suzanne de Villeneuve; published in 1740, it was not a children's tale, but a lengthy romance concerned with the preservation of social class distinctions and civility (Altman and De Vos 3). A second version of the tale was retold soon thereafter in 1756 by Madame Le Prince de Beaumont (4). A governess, Madame de Beaumont adapted de Villeneuve's story as a didactic piece for the edification of young ladies and published it as an exchange "between a Governess and Several Young Ladies of Quality" (4). Shorter and more accessible than de Villeneuve's complicated novel, de Beaumont's tale is the one that has become "the classic model" for subsequent versions of "Beauty and the Beast" (4).

Adapted by Madame de Villeneuve for the romantic sensibilities of her eighteenth century audience, Apuleius's "Cupid and Psyche" episode from The Golden Ass $\left(2^{\text {nd }}\right.$ century C.E.) is cited as one of the sources behind "Beauty and the Beast" (Hearne 15). De Villeneuve emphasizes feminine integrity and filial responsibility, granting Beauty the choice to sacrifice herself for her father and move to the Beast's palace. In de Villeneuve and de Beaumont's tales, Beauty is required to make this choice of her own 
free will, a point that is stressed by the Beast. Apuleius's Psyche, unlike Beauty, finds herself delivered to Cupid's domain without her consent, and discovers that she may not know her husband except under cover of darkness. Suspecting that she has married a monstrous being, Psyche only learns that her husband is the god of love when she falls prey to the jealousy of her sisters and is convinced by them to murder her unseen lover. Following their advice, Psyche prepares to stab Cupid but stops herself when the light of her lamp reveals her husband's identity. Having promised Cupid that she would not allow herself to be swayed by her sisters or give in to her curiosity, Psyche is made to lament her folly when Cupid flies from her and she faces the wrath of his mother, Venus, who sets a series of seemingly impossible tasks for Psyche to complete before she is reunited with Cupid, after Jove's intervention.

Whereas Psyche must pledge herself to an unknown being, Beauty travels to the Beast's palace with the knowledge that she will meet a creature that terrified and threatened her father. As Psyche finds delight in Cupid's home, Beauty also finds that the Beast's palace is a magical place filled with luxury and pleasure. However, though Psyche becomes Cupid's wife when first they meet, Beauty comes to know the Beast before she agrees to marry him. One of the most significant elements of the "Beauty and the Beast" plot, the lengthy association between Beauty and Beast, and Beauty's subsequent decision to marry the Beast because she appreciates him in spite of his appearance, sets this tale apart from others that feature the love-at-first-sight motif.

\section{de Villeneuve's Tale}

While both Madame de Villeneuve and Madame de Beaumont's stories are concerned with the exercise of feminine virtue, Madame de Villeneuve's version of the 
tale differs from Madame de Beaumont's in its treatment of class. Beauty, the daughter of a merchant, grows up amid the luxury and comfort of city life, but loses this when her father's shipping business fails and the family is forced to move to the country. While country life does not suit her five spoiled sisters, Beauty's brothers are kind and hardworking, and Beauty herself toils in an effort to support her father. No sacrifice is too great for Beauty, and her virtuous nature attracts the scorn of her sisters. When the merchant learns that one of his lost ships has returned to port, he asks his children what they would like him to bring them from his trip to the city. While her sisters ask for extravagant gifts, Beauty asks for a rose, not having seen a rose since leaving the city.

Finding that his journey to the city is a failure, the merchant makes his way back to his family and finds an enchanted palace after becoming lost in the woods. In this palace there are more luxuries than the man has ever seen and he is attended by invisible servants. The merchant, finding the place empty, formulates a plan to bring his family to live in the palace. As he is about to leave to share his good fortune with his children, the merchant sees a rose bush in bloom and takes one of the flowers. It is now that the Beast appears and makes a bargain with the merchant-he will spare the merchant's life if one of his daughters is willing to join the Beast in her father's place. Any daughter will do to satisfy the Beast's demands, but Beauty is the only one of the six daughters who is willing to sacrifice her life for her father's.

Despite her fear of the Beast, de Villeneuve's Beauty receives a vision of a young man who warns her that all is not as it seems, and that her journey to the palace has the potential to provide her with great happiness. In the palace, Beauty leads a decadent life; viewing plays and operas performed on the best stages, courtesy of a magic glass, Beauty 
fills her days with entertainment, only meeting the Beast in the dining hall for dinner, where every evening he asks her to marry him. Throughout the course of her time in the palace, Beauty has little to do with the Beast, who is unintelligent and has no talent for conversation. Instead, Beauty comes to know the young man whom she first encountered in her dream. Every evening she meets this man when she falls asleep and soon professes her love for him, admitting that she cares for no one but him, and would marry him if she could. However, when Beauty leaves to visit her family and finds that the Beast has made her father a wealthy man in return for her company, Beauty begins to consider her duty to the Beast for his generosity and realizes her devotion for him when she returns to the castle and finds him dying. Breaking the spell, she finds the young man that appeared to her in her dreams. Beauty is pleased but discovers that her would-be husband's mother, a warrior queen, disapproves of her because of her inferior station. However, the good fairy who watched over the Beast now reveals that Beauty is the lost daughter of the fairy's royal sister and, therefore, surpasses the queen and her son in rank and station. Beauty is rewarded for her goodness, but this is seen as a sign of her innate nobility.

The remainder of the story tells the tale of the Beast's youth, his warrior queen mother, and the old, spiteful fairy that fostered the young man and turned him into the Beast when he refused to marry her. It also tells of how Beauty became a changeling child. However, much of the second part of the story is concerned with class and the maintenance of class distinctions. Beauty brings the promise of wealth to her family, but she is above them because she is of the true aristocracy, they merely receive the gifts of her wealth. The Beast is also rewarded by the nobility of Beauty's character, her sense of 
duty, which arises from her noble nature, as the fairy later reveals, and allows her to understand the choice that she was destined to make since birth.

\section{de Beaumont's Tale}

In contrast, visions, fairies, and matters of class do not complicate Madame de Beaumont's La Belle et la Bête (1756); instead, this tale is concerned with the cultivation of feminine virtues-particularly, filial piety, education, patience, and a woman's sense of duty (de Beaumont was, after all, a governess). Like its predecessor, de Beaumont's tale features a luckless merchant, but de Villeneuve's dozen siblings have been reduced to three sons and three daughters. All six of the children are well educated. Of the three sisters, the youngest is nicknamed Beauty because of her pretty face and sweet temper. Her sisters, on the other hand, are spiteful, arrogant, and selfish girls, only interested in pleasure. One sister insists that she will only marry a duke, the other a count, and so they make rich matches, only to find them broken when their father's misfortune results in the loss of their lovers' favors. While her sisters are shunned by the townspeople for their arrogance, Beauty is admired for her fortitude and wished well; and she receives numerous proposals from gentlemen willing to restore her to the style of life she once led. Beauty, nevertheless, rejects these proposals, as filial responsibility takes precedence over personal pleasure.

After the family moves to the country, Beauty takes on the household chores, though her sisters refuse to take part in the housework, spending their days regretting the loss of their elegant lifestyle. Every day Beauty wakes before dawn, prepares her family's breakfast, performs her chores, and then finds the time to "read, [play] the harpsichord, or [sing] while spinning," becoming stronger in her industry and cultivating her feminine 
graces (de Beaumont 234). After a year in the country, the merchant learns of a ship that has returned to port, asks his daughters what they wish for, and receives Beauty's request for a rose. Beauty, however, does not really want a rose, but she "[does] not want to set an example that [will] disparage her sisters, who would have said that she had requested nothing to show how much better she was" (235). Finding a lawsuit, instead of the profit that he hoped to gain by his journey, the merchant returns to the country in the middle of winter, becomes lost in a snowstorm and reaches the Beast's palace. After spending an evening being served and waited on by unseen servants, the merchant prepares to leave when he notices the Beast's rose garden and plucks a rose for Beauty. Learning the reason for the merchant's offense, the Beast demands that one of the daughters travel to the palace "voluntarily to die in [her father's] place," or the merchant return to receive his punishment (236).

In this version of the tale, the merchant does not consider sacrificing his daughters, or opposing the Beast; instead, Beauty volunteers to travel in her father's place, the thought of her father's death being more painful to her than her own grim prospects. While her sisters blame her for this new misfortune, Beauty is resolute in her decision: "Since the monster is willing to accept one of his daughters, I intend to offer myself to placate his fury, and I feel very fortunate to be in a position to save my father and prove my affection for him" (237). Hence, when she meets the Beast, Beauty is able to "[summon] her courage" and assure him that she came to him of her own free will (238).

Unlike de Villeneuve's tale, where Beauty spends her days in solitary idleness, de Beaumont develops the relationship between Beauty and Beast, as Beauty learns of the 
Beast's kindness (he sends her father gifts to ease her family's poverty), and the Beast learns of Beauty's goodness and virtue. Beauty, envied and hated by her sisters for her beauty and kindness, sees past the Beast's monstrous exterior and appreciates him for his character: "There are many men who are more monstrous than you ... and I prefer you with your looks rather than those who have pleasing faces but conceal false, ungrateful, and corrupt hearts" (240). Finding a friend in the Beast, Beauty only regrets that she must disappoint him every evening when he asks her to marry him.

After some time in the palace, Beauty wishes to visit her family, and the Beast, who can deny her nothing, sends her by way of a magic ring. Her sisters, learning that Beauty has been leading the kind of life that they so crave, plot against her to delay her return to the Beast's palace and, hence, destroy the Beast's faith in Beauty and lose her his favor. Beauty's sisters nearly succeed; by the time that Beauty realizes their deception, the Beast is nearing death. It is at this time that Beauty realizes that, while she did not initially love the Beast, she appreciates his company and respects his character, which is more than her sisters can say of their own husbands. Pledging to marry the Beast, Beauty breaks the curse and is rewarded. Because Beauty "preferred virtue over beauty and wit, [she] deserve[d] to find these combined in one and the same person" (244). In turn, Beauty's wicked sisters are transformed into statues, sentenced to watch their sister's happiness until they have learned the error of pride and envy.

\section{Beauties and Beasts Retold}

A "retelling" generally examines or reveals a different aspect of the story and characters involved in a particular tale, while maintaining the overall theme of the tale upon which it is based. Madame de Beaumont's "Beauty and the Beast" truly is Beauty's 
story, focusing on her situation and her compassion for the Beast. As a result, most retellings focus on Beauty's experience, her relationship with her siblings and father, her request for the rose, her choice to join the Beast, and the interaction between these two. In this thesis I will examine three modern retellings of "Beauty and the Beast": Robin McKinley's Beauty: A Retelling of the Story of Beauty \& the Beast (1978) and Rose Daughter (1997), and Donna Jo Napoli’s Beast (2000).

Adapted from Madame de Beaumont's tale, Robin McKinley's Beauty presents the story of Honour, nicknamed Beauty. However, whereas de Beaumont's Beauty is a paragon of physical beauty and feminine grace, Honour is a tomboyish, gangly girl with low self-esteem. Hope and Grace, Honour's doting sisters, come to represent ideal models of feminine virtue in her estimation. Consequently, Honour's inability to emulate her sisters is a source of consternation for her. Honour's nickname, Beauty, also becomes a source of dismay. Requesting that her father call her Beauty when he is unable to adequately explain the meaning of honor, Beauty grows to regret her childish demand and believes it mocks her appearance. This Beauty's story is a quest for identity and selfacceptance, a psychological self-education that supplements the knowledge she acquires through her studies and experiences. In "More than Skin Deep," Ellen R. Sackelman argues that it is Beauty's negative self-image that becomes the sole antagonist in the story. Only when Beauty embraces all aspects of her self, her androgynous roles, her power, and the beauty that is unlike the traditional prettiness of her sisters, can she become self-actualized.

Another retelling, McKinley's Rose Daughter, focuses on Beauty's personal integrity and choices as she moves towards a full state of being. More surreal than 
Beauty, Rose Daughter is a challenge to explain, the intricacies of the plot being similar to those found in de Villeneuve's fantastical tale. Beauty, her merchant father, and her sisters, Lionheart and Jeweltongue, live as strangers in the family's city estate. While Lionheart and Jeweltongue are not the intentionally cruel and spiteful sisters featured in the original tales, they have strong personalities that make them appear temperamental and generally dissatisfied. Beauty, unlike Honour, is beautiful and possesses every feminine grace, but prefers the seclusion of the garden to social interaction, losing herself in the quiet company of her flowers. But after the loss of the merchant's fortune, the family comes together, and Beauty begins to emerge as an individual, finding pleasure in the company of her sisters and discovering a love of roses when the family moves to Rose Cottage. Consequently, it is Beauty's love of roses that initiates her self-discovery, as her request for a rose allows her transition towards a "selfish" state of being and results in a satisfying, companionate relationship with the Beast. Eliminating the concerns that guide Honour's quest in Beauty, Rose Daughter presents a Beauty who must overcome her own habitual self-denial in order to lead a fulfilling existence.

Donna Jo Napoli's Beast, on the other hand, concentrates on the loss and rebirth of the self as experienced by the Beast, Prince Orasmyn, after he is transformed and cursed to live as a lion. As both lion and man, Orasmyn experiences an identity crisis resulting from the ambiguities of life as a Beast. Although Napoli reduces Belle's part in the story, concentrating on Orasmyn's years under the spell, the connection that occurs between these two calls attention to the effects of isolation and displacement on the Beast's sense of self, while the male perspective provides a contrast between gendered views of the basic plot that also informs these three retellings. 


\section{Folktale Elements}

Betsy Hearne, in her survey of the "Beauty and the Beast" tradition, identifies five "stable elements" that appear in every retelling of the tale, lending a sense of origin and continuity to new versions of the story (Altman and De Vos 10). These elements are as follows: the seasonal shift, the transition from city to country to palace, the rose, the Beast's garden, and magic (10). Narrators change with each retelling; characters are introduced, and details are modified, but these key features remain constant. Beauty, her father, and the Beast are also constants. Additionally, Beauty is "always isolated in some way" $(10-11)$. The seasonal shift refers to the winter to summer, summer to winter transition that occurs in the story. The merchant encounters the Beast after he loses his way in a snowstorm, the last of the season. However, the lands surrounding Beast's enchanted palace are in the bloom of summer. When Beauty leaves the Beast to return to her family, it is summer, but she returns to find the Beast dying in a wintry, stormy setting.

Journeys, as Altman and De Vos explain, are essential to the story, these advance the plot and act as "metaphors for Beauty's inner journey" (10). Beauty travels from the city to the country, and then from the country to the Beast's palace, only to return to her country home before claiming her place with the Beast. These journeys coincide with her growing awareness. In Beauty, the journey to the country allows Beauty (Honour) to experience herself outside the highly defined gender roles of the city, her journey to the palace then allows her to see herself in a new light. Following the same pattern, Rose Daughter's Beauty begins to assert herself while in the country and finds her will in the Beast's palace. Though Belle's experience in the country does not receive much attention 
in Beast, when she goes to the palace she finds the courage and authority her family denied her. Each Beauty makes the return journey to her family, only to discover that the attachment she feels toward them changed in light of her relationship with the Beast. The return to the palace and the encounter with the dying Beast is the last step in her journey, the moment at which she must decide her future.

The rose is also constant, though the significance of Beauty's request may change. Honour asks for rose seeds because she would like to plant a garden, and because she has not seen a rose since she left the city. Beauty has never seen a rose, though she has known their scent since childhood. It is not until she arrives at Rose Cottage and brings the dormant rose garden back into bloom that she finds that she cannot live without them. She asks for a rose when bad weather causes her blossoms to fail. Belle asks for a rose because they are her favorite flowers and, like de Beaumont's Beauty, does not want to appear stingy and priggish before her extravagant sisters. Nevertheless, a rose is never just a rose. They are often associated with the Beast's life and Beauty's hopes.

The Beast's garden is often the setting of change. Here the merchant plucks the rose that alters Beauty's life, and here Beauty returns to find the dying Beast and make her choice. Magic also refers to more than just the Beast's transformation. In Beauty, magic produces roses that bloom in a month, riches that appear out of thin air, and the curse that she must break. Magic is much more present in Rose Daughter, where sorcery and practical magic lay the foundation for the curse that influences Beauty and almost leads her astray. Without any magic of his own, "magic" is what Orasmyn creates in his limited capacity as he transforms the garden around his abandoned castle into a lush paradise for Belle. 


\section{Self-Actualization and the Hero[ine]'s Journey}

Though I will not refer to any specific theoretical concepts in my analysis of selfhood in Beauty, Rose Daughter, and Beast, my reading is informed by an understanding of Jung's theory of the self and individuation. In these three novels, individuation can be read as a journey whereby characters acquire self-awareness by examining their position in relation to others. Beauty and Rose Daughter emphasize Beauty's self-discovery; however, an analysis of Beauty's relationship with the Beast in these novels can also support a reading of self-actualization as a mutual process. On the other hand, Beast is strictly Orasmyn's story; though Belle's involvement is essential to Orasmyn's individuation, only Orasmyn can reestablish his identity as a man.

Individuation, or self-actualization, according to Jung's theory, is "a process of differentiation," the goal of which is the "development of the individual," or Self (qtd. in Campbell, Jung 103). This process is a challenge; to become self-actualized (to know oneself) presupposes an acknowledgement of all aspects of the psyche, both positive and negative. In Beauty, this translates into Honour's need to accept the unique position in which she finds herself, a woman with a "masculine" will and the strength to be a hero. In Rose Daughter, Beauty must reveal her "selfish" side and understand that she need not sacrifice herself for the sake of familial unity. Orasmyn, on the other hand, has to realize that his pride keeps him from his goal; he must accept his own weakness and forgive himself before he can return to his human form. The transformation of the Beast sets up the fairy tale ending at the conclusion of each novel, but this transformation is not limited to the Beast; Beauty is also altered by the experience. Honour becomes the Beast's queen, comfortable in her own skin and satisfied in her role; Beauty emerges as an active, 
determined individual, and Orasmyn becomes a new man. The union that results from this mutual transformation can be likened to the complementary union of anima and animus, the Beast's physical estrangement from the world reflecting Beauty's emotional isolation, even as Beauty's goodness reflects the Beast's inner being. My conclusion, as a result, focuses on the journeys leading up to these transformations, the "heroic" deeds accomplished by Honour and Beauty in their quests for self-awareness, and the psychological battle experienced by Orasmyn. 


\section{Chapter II}

\section{To See Oneself: Beauty's Quest to Find Her Self in Robin McKinley's Beauty}

Considered one of the most memorable modern retellings of the "Beauty and the Beast" tale, Robin McKinley's Beauty: A Retelling of the Story of Beauty \& the Beast (1978) faithfully adapts Madame Le Prince de Beaumont's classic, La Belle et la Bête (1756), while now adding layers of significance to the original storyline, which was already rife with gendered implications. McKinley's version of the story challenges many of the traditional elements associated with gender, reevaluating gender roles and relationships without losing the fairy tale quality. The similarities and differences between de Beaumont and McKinley's texts reveal the implications of gender in Beauty's story. The portrayal of true femininity and the qualities that a young woman must cultivate in her move towards maturity drive Beauty's choices in both stories, but in different directions. Whereas Madame de Beaumont's Beauty upholds traditional feminine qualities throughout the course of the story, McKinley's Beauty repudiates idealized femininity.

Briefly commenting on the history of Madame de Beaumont's "Beauty and the Beast," critic and translator Jack Zipes explains that de Beaumont's didactic piece emphasizes the "proper upbringing of young girls like Beauty ... [stressing] industriousness, self-sacrifice, modesty, and diligence" as traits that young women must acquire if they are to fulfill their intended roles as wives and mothers (Zipes 232). Embodying these ideals, Madame de Beaumont's Beauty finds happiness in her role as a virtuous and self-sacrificing woman. Well-educated, Beauty stands out not for her intelligence, but for her forgiveness and willingness to place the happiness of others 
before her own, for which she is rewarded. In contrast, McKinley's Beauty must relinquish her own idealized concept of femininity to establish her worth as an individual and find satisfaction in her self (the reward that she gives herself). Thus, McKinley's Beauty challenges Madame de Beaumont's portrayal of fulfillment through the cultivation a feminine ideal; instead, McKinley emphasizes the manner in which Beauty's relationships shape her self-awareness and influence her journey towards individuation.

Unlike Madame de Beaumont's Beauty, whose character remains unchanged throughout the story-Beauty's virtues are readily apparent to herself and othersMcKinley's Beauty struggles to establish her identity, discovering her self through her relationship with others, and rewarding herself by becoming a self-actualized individual. Initially, her relationship with her sisters establishes an idealized feminine standard that emphasizes Beauty's shortcomings as a female and stifles her individuality, as it forces her to overlook her personal worth. From her father, Beauty gains her initial awareness of the meaning of honor and beauty, and finds a source of comfort in his acceptance of her singular traits during her childhood in the city. However, her father's unconditional love restrains Beauty within her role as daughter, resulting in conflicting emotions that stifle Beauty's emerging feelings for the Beast as she becomes sexually aware.

Moving away from the city, after the loss of her father's fortune, Beauty finds a confidant and companion in her brother-in-law, Gervain, who introduces her to country life and helps her find a niche for herself as an active member of her household. Moreover, Beauty's easy relationship with Gervain signals her transition away from the filial love that she feels for her father, establishing her first companionate relationship with a male, and easing the way for her emotionally charged relationship with the Beast. 
However, it is Beauty's relationship with the Beast that finally allows her to mature into full individuality. Removing her from her family, the Beast encourages Beauty to acknowledge her inner strength and perceive the honor and beauty that she ignored when in the company of her father and sisters. Thus, the Beast sets Beauty's final transition towards adulthood into motion. Uncertain of her feelings for the Beast, Beauty must accept her honor and sensuality in order to reward herself; it is only after she becomes whole that Beauty can save the Beast.

\section{The Effects of Sisterhood}

A crucial element in both stories, Beauty's relationship with her sisters establishes Beauty's identity as a female. However, whereas de Beaumont accentuates Beauty's goodness (her kind, self-sacrificing nature) through the cruelty and selfishness of her sisters, McKinley complicates the relationship between Beauty and her sisters, as their virtues and accomplishments create a sense of personal inadequacy in Beauty. Madame de Beaumont introduces Beauty as the youngest of three pretty girls, "but everyone admired the youngest one in particular... [and] called her simply 'Little Beauty'.... as a result it led to a great deal of envy on the part of her sisters" (de Beaumont 233). Beautiful and mild-mannered, Beauty unwillingly incurs the wrath of her sisters, tainting their relationship throughout the story and revealing Beauty's virtuous nature as she repeatedly forgives her sisters for their harmful actions. In turn, Beauty's envious and treacherous sisters reveal her nobility through their vices, demonstrating the negative qualities that young ladies must reject if they desire true satisfaction in their lives. Consequently, Beauty receives love and wealth as rewards for her unwavering kindness, 
while her sisters are transformed into sentient statues, so that they may bear witness to their sister's felicity and learn from her virtuous example.

In contrast, McKinley's Beauty enjoys a genial relationship with her sisters, Grace and Hope. But for Beauty, these sisters represent the ideal of true womanhood that she believes herself incapable of attaining. As such, Beauty's belief in her personal faults undermines her self-awareness and sense of self worth. Unlike Madame de Beaumont's beautiful and virtuous Beauty, McKinley's Beauty describes herself as "thin, awkward, and undersized, with big long-fingered hands and huge feet" and an embarrassing case of adolescent acne (McKinley 4). On the other hand, Grace and Hope mature into beautiful, near replicas of their dead mother--a romanticized figure reflected in the two sisters, who act as Beauty's surrogate mothers. In the absence of her birth mother, Beauty idolizes her sisters, holding them up as the touchstone through which true femaleness can be determined. As such, Beauty consistently holds herself to this standard, determining her shortcomings by observing the beauty and accomplishments demonstrated by her sisters (both girls are social, romantic, and adept at creating delicate needlework). Moreover, unlike the cruel sisters in de Beaumont's tale, Grace and Hope genuinely care for their sister, a fact that distresses Beauty, who cannot find a single flaw in either sister against which to assert her own virtues, and cannot dislike them for their goodness. As a result, Beauty must overcome her self-imposed standard by discovering her own virtues, and establishing herself as a being independent of the image represented by her sisters.

Avoiding society, Beauty establishes a close relationship with her family that makes up for her limited social interaction, but provides her with little scope for personal development and limits her self-awareness. With Grace and Hope as her main 
companions, Beauty sees herself as boyish and unromantic. Feeling out of place during one of Grace's tea parties, Beauty warily handles a teacup that she considers much too delicate for her large, masculine hands. When the topic of love arises, Beauty's discomfort increases because of her inability to comprehend the miseries of love described by her sisters. When Hope declares that Beauty is "not the slightest bit romantic," Beauty accepts her statement as yet another difference between her and her sisters (10). As she grows older, Beauty's failure to experience romantic feelings keeps her close to her family, not because she is incapable of love, but because Beauty believes herself unworthy of another's love, deeming herself physically undesirable and unprepared for marriage. Thus, Beauty's dormant sexuality becomes another of her selfperceived faults, and her unresponsiveness when approached by members of the opposite sex increases the list of traits that prevent her from attaining the ideal embodied by Grace and Hope.

\section{The Question of Honor - Beauty and her Father}

Through her relationship with her father, Beauty first becomes aware of the difficulty that surrounds the question of honor and the meaning of beauty. Although Madame de Beaumont's heroine is aptly named by her admirers, McKinley's Beauty chooses her nickname when she is five years old, requesting that her father call her Beauty after he fails to explain the meaning of her birth name, Honour. However, in her transition towards adolescence, both names-Honour and Beauty-become sources of discomfort for Beauty. Given that Beauty's opinion of her physical self falls below the standard of beauty that she established through her admiration of her sisters, honor 
becomes "the best that [can] be said of [her]" (5). Ultimately, Beauty must learn to define these qualities in her own terms to successfully develop a sense of identity.

Moreover, though Beauty's relationship with her father receives equal attention in both stories, de Beaumont employs their affectionate connection to reveal Beauty's selfsacrificing personality. McKinley, on the other hand, portrays a satisfying filial relationship that allows Beauty to turn to her father for reassurance when her desires exceed the options available to her as a well-bred lady. However, despite the reassurance that Beauty gains from her father, she regards his confidence in her abilities as the optimism of a doting parent who cannot see the faults of his child. While living in the city, McKinley's Beauty views herself as a misfit within the lively social circle that her sisters embrace; instead, Beauty prefers the company of books, hoping to one day study at University, though it is "unheard-of that a woman should do anything of the sort" (6). Identifying herself as a plain girl with unfeminine desires, Beauty believes that her looks and personality have "let the family down," and concludes that her father's pride in her distinct personality results from a case of "generous blindness" that keeps him from seeing her failure as a woman (5).

McKinley's Beauty explains that her father's "blindness" allows for the comfortable relationship that develops between them, creating an environment where Beauty can express herself freely, describing her "dreams for the future, without fear of his pitying [her] or doubting [her] motives" (5). Whereas others regard Beauty's "cleverness" as a pitiable trait in a girl, her father accepts her intelligence and studiousness without condition (6). However, Beauty concludes that intelligence, like honor, reveals her "limited worth," and her father's blind faith in her abilities (6). Thus, 
lacking the accomplishments associated with young women in her society, Beauty believes that her father's acknowledgment of her cleverness is another way of "damning [her] with faint praise" (6). As such, Beauty imposes social expectations upon her relationship with her father, concluding that the fault lies in her personality and her father's affectionate disregard of her flaws, not in the rigid roles imposed upon young ladies of her station. Therefore, Beauty also blinds herself, but Beauty's is an ungenerous blindness that rejects the positive qualities that she possesses while focusing on the traditional feminine traits that she lacks.

However, through the loss of his fortune, Beauty's father inadvertently creates an opportunity for his daughter to find some release from her unsuccessful role as a lady, and grants her the ability to find some common ground with Hope. In keeping with de Beaumont's story, Beauty's father loses his fortune after a failed business venture, relocating to the countryside where the moderate cost of living allows the family to lead a humble existence. Moreover, while de Beaumont's Beauty follows her father with the intention of acting as his caretaker, McKinley's Beauty willingly follows her family because she is certain that her departure from the city will have little effect on her. Finding that the move provides a new beginning for her family, Beauty realizes that she and Hope are the ones who are most likely to see the advantages that accompany the change. For Hope, the move represents freedom from the social conventions that impeded her marriage with Gervain, a blacksmith in her father's employ. Likewise, Beauty escapes from the conventions that limited her experience in the city, establishing herself within her family through the androgynous role that the country's lack of restrictions allows her to engage in. Thus, Beauty views the loss of her city life an as an "adventure," 
arguing that she "[has] never been afraid of hard work, [has] no beauty to lose, nor [will she feel] any wrench at parting from high society" (18). The industriousness required of all the citizens of Blue Hill (their new hometown), offers Beauty a respite from the social decorum of the city. Consequently, the opportunities that await them allow Beauty to share in her sister's enthusiasm for the simple country life that they will lead, an enthusiasm that supports their father and Grace through their loss, and allows Beauty to develop her first relationship with a male other than her father.

\section{Country Life - Beauty and Gervain}

Aside from the fresh start that the country offers her family, the move affects Beauty's role as she comes to accept the ambiguities of her position. This change is facilitated through Beauty's relationship with Gervain, who assists her in her search for worthwhile employment, helping her find a place for herself within the household and among the citizens of Blue Hill. In the countryside, Beauty's sisters adapt within their new roles, easily becoming nurturers and caretakers, and occupying their time accomplishing their daily tasks as housekeepers. However, finding that her domestic skills are as ineffective in the country as they were in the city, Beauty reluctantly stops trying to emulate her sisters. Though unable to help with the management of the house, Beauty also finds that she cannot engage in the ironwork and carpentry that her father and Gervain perform to support the family. Instead, Beauty manages those tasks that are too physically demanding for her sisters, but which are too time-consuming for the men, their "real" work taking precedence over the odd jobs that Beauty completes. As such, Beauty describes her work as "what was left over, the odds and ends that were neither house- 
work nor shop-work; and often thought that it would have been much more convenient if [she] had been a boy-not the least because [she] already looked like one" (39).

Able to do neither man's work, nor woman's work, Beauty must reevaluate the effect that gender roles have on her self-awareness, finding satisfaction in individuality, rather than limiting herself within a socially constructed role. Unable to perform male work, Beauty, nonetheless, desires more than the female role of housekeeper permits. However, as Ellen R. Sackelman argues in "More than Skin Deep," though Beauty does not regard housekeeping as an avenue worth pursuing (making no attempt to improve her housekeeping skills, Beauty seeks alternative work instead), this does not signal a complete rejection of the female role; Beauty values her sisters' labor, but she needs something more to feel satisfied with her own labor (33). Unaware that what she requires to experience true satisfaction is a role that conforms with neither masculine nor feminine ideals, Beauty's desire to support her family results in her association with masculine roles.

Through her relationship with Gervain, Beauty establishes her presence in Blue Hill, finding an occupation that supports the androgyny that she requires, allowing her to maintain her unique identity and provide for her family. Nevertheless, Beauty is as yet unprepared to accept the full implications of her position, though Gervain begins to make her aware of her strengths through his support of her individuality. Occupied in his carpentry, Beauty's father no longer serves as Beauty's confidant; instead, Gervain takes on this role, becoming both tutor and counselor for Beauty in all things practical. Under Gervain's tutelage, Beauty learns the proper procedure for uprooting fallen trees and gathering firewood, which establishes her place in Blue Hill and grants her the 
opportunity to work. As news of Beauty's efficiency spreads, the townspeople barter for her services, offering her household items and baked goods as recompense. Although the townspeople make no direct references regarding Beauty's tomboyish personality, Beauty perceives the difference in their treatment of her and her sisters, and reaches her own conclusions about the appropriateness of her adapted role, that her work is accepted by the townsmen because she resembles a boy. Beauty finds that while her sisters receive deferential nods and the occasional bow from the townsmen, she is "hailed with a wave and a grin", or "clapped on the back and given mugs of small beer" (McKinley 40). Treated as one of the boys, Beauty concludes that her appearance, "short and plain and [with] no figure to speak of... [makes] her ambiguous position easy enough to accept" (39). Thus, she overlooks the fact that the strength that Gervain first perceived in her allows for her acceptance among the men, while her sisters' sensibilities bar them from the roughhousing that the men freely engage in when Beauty is among them.

Functioning as a precursor to the Beast as an agent for Beauty's self-actualization, Gervain aids Beauty's journey towards maturity, supporting her development as an individual by acknowledging her choices and her strengths. As such, Beauty's unconventional relationship with her brother-in-law challenges her perception of those traits that she considers unfeminine- her need for knowledge and her steadfastness-and encourages a new self-perception that evolves through her later relationship with the Beast. Warned against entering the woods that surround her home, Beauty wanders towards the edge of the forest, curious to know why this area is forbidden. Catching her, Gervain realizes that intimidation and vague warnings will not satisfy Beauty's need for rational evidence, nor will they dissuade her from entering the forest. Revealing his 
respect for her, Gervain establishes Beauty as his equal, confiding in her by offering her a complete explanation of the local lore regarding the area. Gervain reminds Beauty that her sisters remain ignorant of the legend concerning the wood, because their sensitive and over-imaginative personalities deter him from informing them about the possible dangers that lurk near their home. When Beauty questions his trust in her, Gervain informs her that he understands that she possesses "the sort of mind that prefers to know things," and that he has "a very high opinion of [her] obstinacy" $(43,46)$. Tellingly, Gervain also reveals that Beauty's father only knows some of the information that he shared with her. Thus, Gervain places Beauty at an advantage over her father and sisters because he considers her strong and mindful enough to accept the truth without creating a panic. Striking a bargain with Gervain, Beauty agrees to stay away from the woods as long as Gervain follows his own advice, thereby establishing her position as Gervain's equal and taking charge of her actions.

Sackelman argues that this development, Beauty's first close relationship with a male other than her father, creates the foundation for the "healthy, romantic relationship" that she forms with the Beast, allowing her to experience a relationship based on mutual respect without the pressure of sexual attraction (33). Guarded with her feelings, and uncertain about her appearance, Beauty prefers male friends to lovers, enjoying the uncomplicated interaction afforded by her androgynous role. Thus, Beauty's inability to conform to traditional gender roles enriches her experience as an individual, creating the basis for a well-rounded personality, rather than restricting her within the confines of the accepted feminine experience. Furthermore, Gervain's treatment of Beauty, his confidence in her abilities and the trust he places in her sense of honor, allows Beauty to 
gain insight on the manner in which others perceive her without the bias of a lifelong family tie. Though Beauty can assume that her father and sisters are obliged to accept her because of their lifelong familial bond, her relationship with Gervain is one based on mutual trust and appreciation. Though related by their connection to Hope, Beauty and Gervain need not maintain such a close friendship. Compared to his relationship with Grace, Gervain's relationship with Beauty resembles that of close siblings. Moreover, as equals, Gervain's relationship with Beauty effectively contrasts her relationship with her father, who confines Beauty within the role of dutiful daughter, overlooking her innate sense of honor and her need to become her own person.

\section{Beyond Family}

Enjoying, but not completely satisfied with the position that Gervain helped her establish, Beauty begins to find peace within her dual role when she takes up gardening, an activity that allows her to combine her desire to fulfill the masculine role of provider, while engaging in the feminine role of nurturer. Sackelman argues that Beauty's efforts as a gardener "[establish] her as an integral member of the family," ameliorating her belief in her redundant position and allowing her to find meaning in her work (33). Moreover, the garden creates the transition that Beauty needs in her journey towards adulthood, allowing her to begin the process of establishing herself as an individual within her family, creating a role that exceeds those established by her familial roles as sister, daughter, and apprentice. In addition, Beauty's role as gardener acts as the catalyst for her move to the Beast's castle and the separation that will allow her to find her identity. Distinguishing her self within her family, Beauty can then begin to transcend the 
limits of her current position as a member of the family unit established by her father and brother-in-law, initiating her transition towards full individuation.

Guided by her sense of honor, Beauty's final move towards maturity creates tension in her relationship with her father and sisters, as she attempts to satisfy their demands and fulfill her own desires. Finding that her family's expectations disagree with her own, Beauty learns that she is ultimately responsible for her self, though her choices and actions might displease her loved ones. Requesting that her father bring her a packet of rose seeds from the city, Beauty initiates the event that will distance her from her family. Returning from his run-in with the Beast, Beauty's father explains the sentence laid upon him for stealing a rose from the Beast's garden in order to fulfill Beauty's wish-he must return to the Beast's castle within a month, or allow one of his daughters to return in his stead, but she must go "of her own free will... [because she] is courageous enough to accept the price of being separated from [her father], and from everything she knows" (McKinley 73). Though the Beast proposes to kill Beauty's father, he promises a different fate for the daughter who willingly joins him, emphasizing separation as the greatest trial that Beauty must overcome (a trial that she must endure if she is to realize her full potential as an individual). Refusing the Beast's offer to send a daughter in his stead, Beauty's father then rejects her choice to return in his place, underestimating the sense of honor and responsibility that motivates his daughter's decision.

Consequently, the question of honor divides the family. Hope and Grace, betraying their virtuous natures, decide that no one should fulfill the Beast's request, despite their father's promise. Therefore, they reveal the one fault that Beauty sought to find in their characters, they lack the honor that Beauty demonstrates when she decides to 
return in her father's place. Adamant that she is "choosing," not "offering," Beauty makes the case for her departure, finding support in Gervain. As such, Beauty takes charge of her life, rather than allow her path to be determined by her father and sisters (75). Though her father and sisters see her decision as a misguided attempt to sacrifice herself, Gervain understands Beauty's determination and argues that she is mature enough to make decisions that affect her future. Unlike Gervain, whose relationship with Beauty allows him to see her as a separate being, rather than part of a larger unit, Beauty's father defines Beauty's identity solely as dutiful daughter and sister. Arguing against Gervain's acceptance of Beauty's decision, her father expresses himself in terms of possession. Concluding that allowing Beauty to go in his stead means that he is "giving" his daughter to the Beast, Beauty's father ignores his daughter's right to choose her own path and the Beast's stipulation that she join him "of her own free will" $(79,73)$. Instead, Beauty's father wishes to restrain her, overlooking the intelligence and determination that he accepted when Beauty was a child.

Leaving the familiar setting of her home, Beauty's choice results in the separation that she needs to accept her physical being and become a fully actualized individual, her relationship with the Beast helping her achieve physical and emotional maturity. As Anna E. Altmann and Gail de Vos argue, Beauty's relationship with her father and sisters keep her attached to "a childish self that she is ready to outgrow" (17). At eighteen, Beauty feels ready for a change; the Beast's offer provides her with such an opportunity. Recalling her earlier description of her journey to the countryside, Beauty describes her choice as her readiness for an "adventure" (McKinley 78). Foreshadowing the role that she will play in her involvement with the Beast, Beauty's description of her journey to 
the castle as an adventure aligns her with the role of knight, a role traditionally reserved for the fairy tale hero, not the heroine. Moreover, though her first adventure strengthened her familial bonds, this second adventure creates an opportunity for Beauty to reevaluate her perception of herself outside the family setting.

\section{Beauty and the Beast}

Beauty's interaction with the Beast allows for the culmination of her growth, encouraging Beauty to define her understanding of honor, and helping her come to terms with her awakening sensuality. As Altmann and de Vos explain, McKinley's view on honor consists of "a sense of inward rightness" and "respect for oneself," emphasizing Beauty's choices as an individual, rather than equating honor with "chastity" (17). The Beast initiates Beauty's recognition of her innate sense of honor when he informs her that he would have sent her father back, unharmed, had he kept his promise and returned without sending one of his daughters. Beauty thoughtlessly says, "You mean I came here for nothing?" to which the Beast replies, "No. Not what you would count as nothing. He would have returned to you and you would have been glad, but you would also have been ashamed, because you had sent him, as you thought, to his death" (McKinley 115). Explaining that she would feel dishonorable and grow to hate herself if she did not act on behalf of her father, Beauty is challenged by the Beast to reassess her perception of honor. Surprised by his understanding of her character, Beauty wonders if the Beast has the ability to foresee future events. Denying any such powers, the Beast explains that he can "see" her (115). Perceiving the strengths that Beauty denies, the Beast sees promise in her. Like Gervain, the Beast acknowledges Beauty's honor and willfulness as 
strengths, an awareness that her well-meaning father lacks. Accepting the Beast's recognition of her virtues, Beauty begins to see them for herself.

As Beauty's friendship with her brother-in-law establishes her first relationship with a male other than her father, introducing her to the possibility of male companionship, Beauty's relationship with her horse allows her to understand the Beast's animal qualities and accept his physical reality. When she rides Greatheart, Beauty overcomes her low self-esteem, sharing in the "dignity" that her great horse lends her (104). Greatheart, purebred and fit for a king, is in his element among the grandeur of the Beast's palace, without him, Beauty feels "small and shabby.... self-conscious and jittery" (104). One of the "Great Horses," Greatheart is not a placid lady's mare, but a steed, "eighteen hands high and taller, descended from the big, heavy horses the knights had used to carry themselves and several hundred pounds of armor into battle" (22). Atop her horse, Beauty feels secure and sure of herself, her confidence increasing because she is certain she "look[s] slightly better in the saddle than anywhere else" (22). As such, Greatheart embodies Beauty's courage and strength; the unique bond between Beauty and her horse encouraging her to take chances and act according to her own rules.

When Beauty determines to join the Beast, she reassures her father by asking, "Cannot a Beast be tamed?," recalling her effort to tame Greatheart, and the success of her endeavor. Patient, compassionate, and unwilling to accept defeat, Beauty earned the young horse's trust. It is Beauty's persistence and empathy that helps her gain the Beast's trust when she first introduces him to her horse. Aware that other creatures feel threatened by his presence, the Beast makes an attempt to dissuade Beauty, but reluctantly gives in, unwilling to deny her. "Greatheart likes whomever I like," Beauty 
argues, certain that she can overcome Greatheart's instinctual fear of the Beast and the Beast's wariness (149). Succeeding in her endeavor, the encounter becomes the first of many between these three, so that soon Greatheart "[is] nearly as comfortable as [Beauty is] in the Beast's company" (158). Encouraged by her ability to overcome Greatheart's natural aversion to the Beast, Beauty's determination to gain her horse's approval of the Beast is reflected in her later effort to make her family understand her growing attachment to the Beast.

Though associated with the role of knight, Beauty also serves the role of lady in her relationship with the Beast, merging masculine and feminine roles, and finding fulfillment in a well-balanced, androgynous persona. Conflicted by her dual roles during her childhood and early adolescence, Beauty continually sought to align herself with either feminine or masculine roles, whether by emulating her sisters, or wishing that she had been a boy. Thus, struggling with herself, Beauty created a fractured identity. Moreover, Beauty's rejection of her physical traits results in a valuation of mind over body that keeps her from accepting her being as a whole. Physically monstrous, but intelligent and amiable, the Beast's external reality reflects Beauty's distorted perception of her own physical being and the isolation that she once preferred. Similar in their dispositions, Beauty and the Beast become companions and equals, subverting the role that Beauty's family casts her in - that of victimized prisoner. Looking past the Beast's exterior, Beauty initially denies her feelings for him, as yet uncomfortable with her emerging awareness of her physicality. As such, Beauty cannot fulfill her knightly role until she accepts her feelings towards the Beast and understands the concept of honor that unconsciously guides her actions. 
Denying her changing perception of the Beast's presence in her life, Beauty requests permission to visit her family, a visit that forces her to reflect on the choices that she must make if she is to settle the conflict within herself and become a fully actualized individual. While visiting her family, Beauty feels like a "traitor," disappointing her father and sisters by informing them that she must return to the Beast's side after a week, and discovering that she feels no remorse at the thought of returning to her new home (208). After six months in the Beast's castle, Beauty feels like an outsider when she returns to her family's home, blaming her feelings of disconnection on her lengthy absence. Consequently, when her father objects to the briefness of her visit, Beauty tries to appease him, arguing that she would prefer to remain with her family, but inwardly discovering that she is anxious to return to the Beast's side (209). Trying to meet everyone's expectations, Beauty finds that she cannot be both victim and savior. Asked to remain for another day, Beauty's sense of honor conflicts with her wish to please her father, but having promised to return, Beauty feels that breaking her promise goes against her better nature. However, even as she consents to stay a day longer, Beauty becomes aware that she no longer belongs in her family home, her needs having surpassed the limited reality offered by their affection for her (228).

Unable to perceive her honor, Beauty's father places her in a position that challenges her love for him and her love for the Beast, forcing her to choose between remaining in the role of daughter, or becoming the Beast's partner. Understanding this, Beauty learns that it is ultimately her choice to decide her fate; thus, she discovers the implications behind the Beast's stipulation that she act of her own "free will" (73). 


\section{Becoming Beauty and Honour}

Taking control, Beauty chooses to act for herself, riding Greatheart to the Beast's castle, but discovering that the magic that guided her first journey is no longer present; she must find her own way through the darkened forest. Refusing to accept defeat, Beauty draws strength from her desire to become whole and find fulfillment. Combining her roles as knight and lady, Beauty finds the Beast and proposes to him, breaking the enchantment that binds him within his unnatural form.

Guided by the sense of honor that would not let her rest until she had completed her mission, Beauty also accepts her physical being, deciding that she is worthy of love when she proposes to her chosen lover. Thus, if honor is, as Altmann and de Vos argue, "what one owes oneself," then Beauty finds the wholeness that she owes herself, balancing her many roles to establish an identity based on personal choice rather than societal expectations, and finding satisfaction in her life with the Beast (17).

Beauty reemerges from her quest as a new person, her identity shaped by the trial she endured in order to reach the Beast and claim her reward. In the Beast's company, Beauty learns to see past the Beast's exterior, coming to know the individual within the beastly form, a new perception that allows her to discover the purpose that she must serve. Nevertheless, despite Beauty's faith in the Beast's sincerity, she repeatedly rejects his efforts to challenge her self-deprecation. Accustomed to her family's acceptance of her faults, Beauty stubbornly maintains that the Beast compliments her because he is kind, or worse, because he has been alone for so long that he has no basis for comparison. When Beauty introduces herself, she apologizes to the Beast for her misleading nickname, certain that her appearance is a disappointment to one who would have 
expected to receive a beautiful woman for his possession. However, the Beast assures Beauty that he has not been disappointed or misled, he "welcome[s] Beauty and Honour" (McKinley 118).

As Beauty comes to acknowledge the Beast's goodness, her perception of beauty shifts, the Beast's character revealing a different kind of beauty that is intimately connected with his honor. There are no mirrors in the Beast's palace; the Beast, regarded as a monster and defined by his appearance, only knows himself as others see him; Beauty, in turn, need not see her supposed flaws. The Beast, however, has no difficulty understanding the honor that guides Beauty's actions, nor does he accept her "[odd] misapprehensions about her appearance" (242). As the relationship between Beauty and Beast is informed by the question of Beauty and Honour, Beauty emerges from her trial with a new understanding of these qualities. Consequently, it is not until Beauty acknowledges her own honor (what she once considered a sign of her "limited worth"), that she can recognize her own form of beauty (6).

Finding the Beast transformed into his human shape, Beauty retracts her proposal, claiming that she is unworthy of such a handsome partner because she is a "dull drab little nothing" (241). Unwilling to accept this rejection, the man who was once the Beast places Beauty before one of the mirrors that was restored to the palace after the curse that bound him was dispelled. Beauty is now able to see herself as the Beast has always seen her. When she visits her family, Beauty realizes that she has grown in stature, measuring her height by the length of her saddle-straps, but remains ignorant of the more substantial physical changes wrought during her months spent in the mirror-less palace. No longer is 
she the awkward, boyish girl that she was before beginning her journey. Seeing Beauty and Honour reflected in the mirror, Beauty is complete.

Unlike de Beaumont's Beauty, rewarded for her virtues, McKinley's Beauty must reward herself. Though her sisters, Hope and Grace, insist that Beauty has returned a changed person, having matured into the beautiful and graceful lady that she always despaired of ever becoming, Beauty fails to recognize such a shift. Accustomed to the constant support of her family, Beauty regards her sisters' compliments as part of their usual effort to discourage the negative attitude that marks her awareness of herself. Nevertheless, despite of the compliments that she receives from the Beast and her sisters, it is not until Beauty recognizes her physicality that she can truly see herself.

Moreover, while Gervain and the Beast both support and esteem Beauty for her honor, their high regard for her strong character is of little consequence until Beauty acknowledges the value of honor. As it is Beauty who chooses to complete her journey and return to the Beast (rather than comply with her father's wish and remain with her family), it is Beauty's decision that creates the possibility for her final transition towards actualization. Thus, Beauty can only become a fully self-actualized individual when she finds the courage to do that which she knows to be right (for her) and honorable. The result of her courageous act is her reward - Beauty becomes a lady-knight alongside the Beast, welcoming the citizens of Blue Hill to the palace, queen-like and satisfied. 


\section{Chapter III}

\section{Following It to Its End: Fate, Choice, and Becoming 'Selfish' in Rose Daughter}

In Rose Daughter, Robin McKinley once again re-envisions "Beauty and the Beast," emphasizing Beauty's character, choices, and involvement with the Beast. Whereas Honor's family is sympathetic and affectionate throughout the course of the story, accepting Honor's differences without question, Beauty, her father, and her sisters (Lionheart and Jeweltongue) merely coexist within the family home, lacking the kind of affection that encouraged Honor's growth as an individual. As their names indicate, Jeweltongue is possessed of a quick, biting wit that she sharpens on suitors and servants, Lionheart is recklessly brave and determined, and Beauty is pleasant and attractive. While her sisters prefer engaging in intellectual salons and hunts, Beauty seeks the company of flowers. As a result, the sisters lead distinctly separate lives while growing up in the city. Embodying the virtues after which they are named, Lionheart and Jeweltongue display decidedly strong character traits, their dominant personalities overshadowing the more passive Beauty. Uncertain of herself and her place within her family, Beauty must overcome numerous trials before coming into her own-a journey of self-discovery that starts with her family's removal to the country and is facilitated by her love of roses. Responding to the life-changing loss of the family fortune, Beauty becomes more assertive, assuming responsibility for the survival of her family, establishing family unity, and learning to interact with others; however, it is Beauty's relationship with the Beast that allows her to become a fully actualized individual as she learns to voice her desires and acknowledge herself as a "selfish" being capable of choosing her own happy ending. 
The first step in Beauty's journey of self-discovery is instigated by her father's ruin as she assumes responsibility for her family's survival. Unable to cope with the loss of his wealth, Beauty's merchant father experiences a physical and mental breakdown that leaves him unable to manage the dissolution of the family estate. The task is, therefore, left to his daughters. Spurned by their associates because of their past behavior, Lionheart and Jeweltongue find themselves friendless. Though brave and clever, neither Lionheart nor Jeweltongue can handle the ignominy of the family's loss, relying on Beauty to perform the tasks required to secure their future. Remaining levelheaded, Beauty finds herself at the head of the family, managing the situation in a manner that surprises her sisters and herself. Relying on her easy ability to interact with others, a talent that neither of her sisters possesses, Beauty contacts those individuals whom she had assisted during the heyday of her father's wealth, mostly people who served her family when she was a child.

Locating a new home for her family in the town of Longchance, a small cottage left to the family by an unknown benefactress, Beauty acquires a newborn sense of authority and decisiveness for the sake of her father and sisters - a variation on the selfsacrificing Beauty depicted by Mesdames de Villeneuve and de Beaumont. Taking full responsibility for her family's well-being, Beauty gathers all the knowledge of country living that neighbors and former servants can impart, sparing her father and sisters the indignity of showing themselves in a town that rejected them after their fall. Displaced from their home, the three sisters and their father learn that they are dependent on each other. Journeying to their new home, Rose Cottage, the family undergoes a dramatic change as Lionheart, Jeweltongue, and Beauty come to know themselves outside of the 
superficial reality of the city. Together, the sisters find a sense of closeness that challenges their former notions of felicity - wealth, servants, titles-finding contentment in the labor and self-reliance of country life.

Nevertheless, Beauty's move towards self-actualization requires more than a change in circumstance; she must reassess her understanding of herself as an individual capable of effecting change through choice, rather than relying on "fate". Unprepared for the implications of her newfound power, Beauty takes to gardening, a task that provides her with a comfortable and familiar setting, and insulates her from the anxiety that results from her changing awareness of herself. Though Beauty first experiences the importance of choice when called upon to assist her family, it is her involvement with the Beast that ultimately changes her perception of destiny and choice. As such, it is Beauty's request for a rose that initiates her move towards a "selfish" state of being.

\section{The Mother's Legacy}

Following the tradition set by other versions of "Beauty and the Beast," in Rose Daughter Beauty's mother is absent. Associated with a "constant glamour and motion," the memory of the Beauty's mother affects the family as a whole, resulting in an underlying anxiety that interferes with their ability to experience the fellowship of family (McKinley 1). For Lionheart and Jeweltongue this translates into a dissatisfying, superficial existence as socialites as they try to maintain the hospitality for which their mother was known. Lionheart, who prefers hunting and riding above anything else, is reckless and destructive as she leaves "nerve-shattered horses, [and] dumbly confused and despairing dogs" in her wake (7). Jeweltongue, in turn, demonstrates her mother's cleverness, but shows a tendency towards cruelty as she derides and belittles her fellow 
intellectuals. Hosting salons, hunts, and parties in the style of those conducted by their mother, both sisters surround themselves with members of their upper-class society despite their obvious disregard for social niceties. Their father, in the meantime, rejects society after his wife's death, bothered by the presence of her former followers. Beauty avoids company and hides in the estate's garden.

Discovering the peacefulness of plants when she is a child, Beauty unconsciously seeks her mother's presence among flowers, her affinity for roses born of her search for the flower that carries her mother's scent. Little more than a toddler when her mother died, Beauty recalls that her mother's world "was very exciting, but it was also rather scary," leading Beauty to find comfort in the garden (3). Plants, she found, were "quiet," they lacked the constant restlessness of her mother's company, but provided her with a sense of comfort (3). A near stranger in her own home, Beauty avoids the wrath of her sisters by slipping into the garden on days "when it seem[s] to her that everyone she [meets] with was either angry or unhappy" (7). Preferring flowers to people, Beauty finds "tranquility" in the garden, "almost as though it were a veil, or as if she had suddenly become a plant herself' (7-8). Disappearing among her plants, Beauty loses her self in her isolation. In her home Beauty becomes a wallflower, blending into the background as she takes on household duties that go unrecognized by her father and sisters. Managing the household accounts without her family's knowledge, Beauty becomes absorbed in her role as unobtrusive caretaker, supervising her family's comfort as she hides behind a selfless persona. Caring for others becomes a means of self-denial for Beauty, who feels that "there [is] too much temper and spitefulness in the house already," and "promise[s]... 
never to add to it" (9). Silenced, veiled, and isolated, Beauty denies herself to avoid increasing the already turbulent environment fostered by her sisters.

Starting in early childhood, Beauty experiences a recurring dream that becomes associated with her earliest and most vivid memory of her mother and the scent of roses. A nightmare wherein she steadily approaches an unknown monster waiting at the end of a darkened corridor, the dream reveals elements of Beauty's character that are concealed by her efforts to foster peace within her home, particularly a determination and selfassurance that the Beauty who hides among her plants lacks. In the wake of her mother's death, Beauty encounters the dream for a second time and finds that the nurses watching over her have little patience for her fears. Without a mother to provide her with the comfort that she craves, and receiving no sympathy from her caretakers, Beauty learns "not to cry out," silencing her fears and demands at an early age (6).

As she grows, Beauty identifies the dream as her only distinction; with its mysterious relation to her mother, the dream becomes the basis for Beauty's identity. Comparing herself to her sisters, Beauty questions whether it is "the dream itself that makes her so different from her sisters" as she finds traces of her mother in her sisters, but fails to find such a resemblance in herself (6). While she notes the talents and traits demonstrated by her sisters, Beauty believes herself limited to her appearance. As her name implies, Beauty is beautiful, but so are her sisters ("They were all beautiful; all three took after their mother.") (6). Embodying the talents after which they are named, Lionheart and Jeweltongue are more attuned to their identities. Beauty, however, sees her beauty as the only visible connection between herself and her sisters, something that they all share and without which she would be as irrelevant as the other servants in the 
family's household. Nevertheless, though her sisters exhibit their mother's cleverness and bravery, Beauty unconsciously demonstrates her mother's determination, a trait that she reveals in her gardening efforts and finds reflected in her dream self.

\section{Finding Community through Family}

Disconnected from society and each other, Beauty's family must establish familial unity before they can find fulfillment within the community. Finding themselves friendless after news of their father's failure spreads throughout the city, Jeweltongue and Lionheart become aware of the emptiness masked by the constant activity of their city lives. Abandoned by their neighbors and learning that their fiancés no longer find them desirable now that their father cannot provide them with dowries, Lionheart and Jeweltongue reject society and look to their younger sister for support. Though accustomed to caring for others, Beauty suddenly finds herself in an unexpected position: now that her sisters have lost their drive, and her father has fallen into a debilitating depression, she has become the center of the family. While her older sisters manage the housekeeping and cooking, Beauty handles the business end of the situation, a change that does not affect her as much as her sisters. Thus, Beauty easily slips into the position of manager, reinforcing the habitual denial and concealment her own anxieties in her effort to alleviate those of her father and sisters.

Coming together as a family after leaving the city, these four begin to experience themselves in the absence of the constricting personas that they maintained when upholding the glamorous and empty lifestyle first established by the merchant's wife. Abandoning their habitual anger, Jeweltongue and Lionheart find contentment in the predictability and simplicity of their new lives, while Beauty begins to flourish in her 
own right, finding a welcome home at Rose Cottage. Sharing the household duties, Lionheart, Jeweltongue, and Beauty find a sense of companionship that eases them into their new lives. No longer are the sisters able to lead completely separate lives, the closeness resulting from their shared duties in the cottage uniting them and increasing their awareness of one another's needs.

However, it is Beauty's dream that truly draws the sisters together. Missing during the intermittent period between her father's disgrace and the family's move to Rose Cottage, the dream abruptly returns, tearing Beauty from her sleep. Sharing a room with Beauty, Lionheart and Jeweltongue become aware of the dream because of Beauty's violent reaction to its return. Learning of the dream's effect on Beauty, her sisters understand the extent to which their relationship has changed since they left the city. That the dream had been an active part of Beauty's life for so long without their knowing shames Jeweltongue and Lionheart, who are now able to appreciate the bond of sisterhood that they dismissed in the past. Though these three perform distinctive roles in Rose Cottage-Beauty gardens, Lionheart cooks, and Jeweltongue sews-the sisters are no longer separated by their individual pursuits, but are able to come together as companions, confiding in each other as they strive to succeed in the country. Satisfied with their new roles, the sisters begin to know their true selves, examining their position in Longchance, within the family, and as individuals.

More than an indicator of the new ties established by the three sisters, the dream's return emphasizes Beauty's increasing self-awareness, becoming a space where Beauty is compelled to examine the willfulness and determination that marks her dream self's character. A part of herself that Beauty believed to be "part of her old life, gone forever," 
the dream's return is as "terrifying as a blow from a friend," shocking in its familiarity and ability to disconcert (29). As a child beauty realized that in spite of her fear of the monster, she "never really tried to run away," her dream self "was determined to follow the corridor to its end, to face the monster," her determination troubling her more than the threat of the monster (6). More intense than when she experienced it in the city, the dream now reflects Beauty's waking actions. As a result, Beauty "force[s] herself to grow accustomed" to its return and to the sensation "that the only difference between her waking life and her life in the dream [is] that in the dream she [does] not know where she [is]" (31).

As she is unable to suppress the desires and emotions that she ignores while awake, the dream holds Beauty responsible for her actions despite her efforts to dismiss the experience as "only a dream" (32). Attempting to overcome the dream and its troublesome revelations, Beauty seeks "details in her waking life that she would not be able to match in the dream," hoping that such a clear distinction "would orient her so firmly to the world of Rose Cottage and Longchance that the dream would distress her less" (31). Defying her wish, the dream captures Beauty's daily observations, reflecting and modifying these until they contain only a trace of the familiar, retaining enough of Beauty's conscious reality that she cannot ignore the similarities. Truly perceiving herself among the familiar surroundings of Rose Cottage, Beauty is then able to locate herself within the dream and understand what her dream self reveals by acknowledging the attraction and compassion that she feels towards the monster. Upset by her inexplicable desire to comfort the threatening, unknown presence, Beauty finds that she "feared him no less for this; she did not even know why she felt pity and grew angry with herself for 
it" (31). Experiencing "grief and pity and raging at herself," Beauty wonders at the emotions that she experiences while dreaming (31). Defying her sense of reason, the sympathy and persistence that her dream self demonstrates raises questions about herself that Beauty remains unprepared for, but which create the possibility for later reflection.

\section{Roses, Fate, and Beauty's 'Selfish' Request}

As her chosen retreat since childhood, gardens provide Beauty with a sense of solace that she can find in no other setting, a place in which to distance herself from all her concerns. When first arriving at Rose Cottage, the family finds that the cottage and the plot of land surrounding it are covered with a tangle of thorny, dead-looking vines. Though Lionheart and Jeweltongue dismiss the overgrown mess and offer to remove the vines, Beauty contends that, despite their ugliness, the arrangement of the plants indicates that they were once well loved. After planting a practical vegetable garden, Beauty dedicates her time to reviving the dormant garden, lovingly looking after each plant and risking the vicious thorns that scratch at her when she tries to prune them. Determined to revive these plants, Beauty risks the annoyance of her sisters, who make it clear that they view the plants as a nuisance and would prefer to be rid of the lot. When the vines bloom to reveal roses, their scent reviving memories of her mother, Beauty becomes so absorbed in her roses that she forgets to care for herself and tend her chores, finding that "if she could do nothing beside a rose-bush in full bloom, she [would be] entirely happy" (46). Finding that when the roses are in bloom, their presence drives her dream away, Beauty is lulled into a sense of contentment that relieves her from the barrage of conflicting emotions inspired by the dream. 
During her second year at Rose Cottage, the dream leaves Beauty once again, disappearing during the flowering season but returning sooner than expected, before the roses have withered. Vehemently rejecting the dream's early return, Beauty departs from her normally quiescent attitude and takes control of the dream, demanding that it "Let [her] go" until its appointed time (56). In this unconscious state, Beauty expresses a strength of character that is hidden by the complacent demeanor that she adopts in her waking life, the veil that she learned to hide behind as a child. Though the roses bloom annually, they fail to blossom during the family's third year in the cottage, the result of bad weather. Generally content with her lot, Beauty feels the loss of her roses more than she felt the loss of her family's wealth, becoming distracted and irritable without them. In the aftermath of her family's loss, Beauty found a purpose in her efforts to care for her family. Well-established and thriving in their new home, Beauty's father and sisters need no longer depend on her; without her roses Beauty loses more than her flowers, she loses her purpose. Breaking the promise that she made to herself in her youth, Beauty neglects her part as peacekeeper, allowing her temper to get the better of her and displaying a never before seen passion that takes her once fiery sisters by surprise. This momentary loss of control is instantly checked, but this slip exposes the quiet dissatisfaction felt by Beauty when she finds that her one desire is denied her.

Previously content to accept her situation without question, Beauty cannot overlook the emptiness caused by the absence of her roses, her once loyal companions, and so permits herself to express what she later regards as her "selfish" desire (80). Receiving news that one of his ships returned to port after it was presumed lost, the merchant journeys to the city on business, asking his daughters what gifts they would like 
him to bring them on his return. In Madame de Beaumont's tale, Beauty requests a rose so as not to appear stingy before her sisters, each of whom asks for luxuries from the city. In contrast, Lionheart and Jeweltongue refuse their father's offer; Beauty, not wanting to disappoint her father, asks for a rose, the one item that she feels essential to her continued felicity. It is this request that initiates Beauty's involvement with the Beast and her move towards a more self-aware (selfish), active state of being.

Venturing into the Beast's enchanted palace after becoming lost on his return to Rose Cottage, Beauty's father, remembering her request, steals a rose from the Beast's table. Perceiving this as poor repayment for the hospitality granted to the merchant, the Beast begins to threaten the merchant's life, but then chooses to offer the merchant a choice. As the merchant explains the reason behind his action, the Beast learns of Beauty's love of roses and ability as a gardener; as a result, the Beast wishes Beauty to join him in return for the stolen rose. The Beast promises that neither the merchant nor Beauty will take any harm from him, but he will claim his due if neither should return to the palace within the appointed time. Making it explicitly clear that Beauty will not serve as a sacrifice, the Beast swears that Beauty "will take no harm of [him]," but she must join him of her own free will (74). "I am lonely here," the Beast explains, articulating his desire for Beauty's presence in order to ease her father's fear, “... as no fierce creatures come here for fear of me, who am fiercer, so no gentle ones come either. I desire companionship" (75). As they share a love of roses, Beauty and Beast also share a yearning for companionship that stems from the loss of their personal gardens.

Convinced that she was "selfish in [her] little, little sorrow," Beauty chooses to comply with the Beast's request, certain that she must "take up the fate [she has] earned" 
(80). Rejecting her father's decision to return to the Beast's palace and spare his daughters, Beauty is resolute in her intention to face the Beast. Consequently, Beauty invokes fate even as she blames her request for her circumstances, certain that the Beast's demand was the direct result of her "selfish" attachment to the rose garden. Beauty, therefore, ventures to the Beast's castle on the pretext that she must accept the fate she earned, "this was her fate...she had called its name and it had come to her, and she could do nothing now but own it" (81). Having learned of a local legend concerning the history of Rose Cottage, a curse requiring that three sisters inhabit the cottage, Beauty, who kept this knowledge from her family, believes her request for the rose and her father's meeting with the Beast are part of the curse. Believing herself cursed, Beauty chooses to join the Beast in order to take her cursed fate away from her family, willingly sacrificing herself though she doubts the sincerity of the Beast's claim she and her father would remain unharmed if she joined him.

Seeming to fulfill the demands of the curse and the dream, Beauty's interment in the Beast's palace provides her with an opportunity to face the monster that she so fears and come to terms with those aspects of herself that she denies-her determination, willfulness, and selfish desires. Claiming fate for her change in circumstances, Beauty assures herself that her journey to the Beast's castle is an inevitable task that she was destined to perform since she first experienced the dream. Assuming that it is her fate to meet, Beauty is steadfast in her intention to join the Beast in her father's place, but overlooks the implications of her choice in the matter. Despite her fear, Beauty is lured by the promise of roses, assuring herself that a Beast who shares her affinity for roses cannot be as awful as she imagines. In Beauty's estimation, it is honorable to sacrifice 
herself for her family, but to admit that she is venturing forth of her own free will, against the wishes of her father, is to admit a "selfishness" that she is unprepared to recognize.

\section{Meeting the Beast - Gaining Control and Becoming 'Selfish'}

Unaware of the control she has over her life, Beauty's belief in fate blinds her to the power that she holds; it is the instability of the Beast's palace that ultimately challenges Beauty's perception of choice and control. Confined within the palace, the Beast only has his roses and Fourpaws, a cat that visits on occasion, to keep him company. Discovering that the Beast's roses are dying, Beauty finds herself capable of sympathizing with the Beast's lot, seeing her own loneliness reflected in his. Vowing to bring the Beast's roses to life, Beauty displays the same persistence that she revealed when she toiled to awaken the dormant garden at Rose Cottage. Though certain that she will find a "friend", Beauty is surprised at the "decisiveness" and determination that urges her to restore the garden $(96-97,98)$. During her first meeting with the Beast, Beauty ascertains that the Beast truly means her no harm; moved by the sadness that she notes in him she makes a "promise to him, [though] of that promise she [does] not yet herself know" (89). Though Beauty convinces herself that restoring the garden is the task accorded to her by fate, it is her unconscious promise to the Beast that drives her in her effort. Supposing that she is only suited for gardening, it is Beauty who determines the role that she will serve and the length of her stay in the castle.

Though accustomed to serving as gardener, both in the city and at Rose Cottage, it is not until she tends the Beast's roses that Beauty finds a definite purpose in her task. Satisfied with her work, Beauty tells herself, "I have something to do; I have earned my bread" (136). Needing to feel as though her actions are worthwhile and meaningful, 
gardening takes on a greater significance for Beauty while she remains in the Beast's palace. Whereas the garden at Rose Cottage became a way for Beauty to occupy herself while Lionheart and Jeweltongue handled the bulk of the housekeeping and completed their own work, tending the Beast's garden fulfills Beauty, her efforts promising to bring pleasure to the Beast and reward her in turn. Once a source of comfort, the rose garden now grants Beauty the satisfaction of knowing that she, like her sisters, has found her niche. No longer aimless, Beauty acknowledges the unconscious promise that she made to the Beast, "she was going to make him happy; she was going to bring his rose-bushes to life- and then she could go home" (132).

As she felt when she first realized that her dream self pitied the monster at the end of the corridor, Beauty is confounded by her growing attachment to the Beast, his sadness and isolation as distressing to her as the pain experienced by her family in her absence. Counting the Beast as her companion, Beauty wants to "think pleasantly" of him and enjoy his company without feeling guilty for her enjoyment (136). Though frightened of the Beast when she first met him, Beauty comes to understand that his wild exterior does not reflect his inner being. Learning that she and the Beast have long shared the same dream, Beauty asserts that, despite her initial fear, the dreaded "monster" at the end of the corridor is not her new companion (104). Choosing to take the Beast's love of roses as a sign of his innate goodness, Beauty sympathizes with his position, viewing him as a fellow prisoner. As a consequence, Beauty is faced with a dilemma; as the reason behind family's distress, Beauty is expected to feel resentful towards the Beast, but her desire to cultivate the Beast's friendship challenges her understanding of what it means to deny herself to please her family. Seeking to keep her family whole, Beauty denies herself any 
desires that might disrupt the ideal of familial unity to which she clings. Beauty assures herself that the return of the roses will free her from her duty and allow her return to Rose Cottage, eliminating her family's troubles and permitting her to slip back beneath the veil of her roses, unchanged by her time with the Beast (7).

As Beauty adapts to her life in the palace, the dream adapts as well, showing her glimpses of her family and instructing her by expanding her perception of Lionheart, Jeweltongue, and her father as individuals outside the family unit. As a result, Beauty becomes aware of her own position as an individual, exploring her relationship with her family, the Beast, and herself. During the first of these new vision, Beauty observes her father and Jeweltongue conducting "ordinary activities," the ordinariness of their actions making her realize that her family seems "so ordinary without her, [that] she wishe[s for] some clear token that they [miss] her" (106-7). Disturbed by this selfish thought, Beauty quickly reassesses the scene, noting her father's pained expression, but finding that in spite of such pain, a part of her "want[s] them to miss her" (107). Sacrificing herself for her father and sisters, Beauty's choice places her in a double bind-for the sake of their well-being and happiness, she left them, but her decision has resulted in their grief. Realizing that searching for a sign of her family's loss is "not right," Beauty finds that knowing of their suffering "ma[kes] her feel more isolated than ever" (107).

Incapable of sharing and alleviating her family's pain, Beauty's dream-self forces her to recognize her decision to join the Beast as a choice made willingly, the effects of which she must accept and manage on her own. As with her family's grief, the Beast's sadness can only be alleviated by Beauty's presence, pulling her in two directions. Before beholding the vision of Jeweltongue and her father, Beauty encounters her usual dream, 
but her changing perception allows her to understand that she is not just seeking the monster, she is "hurrying to come to the end of [the corridor], to comfort the sadness that hid[es] itself there" (106). Beauty knows that to remain as the Beast's companion will only generate more grief for her family, yet, as her dream-self reveals, Beauty cannot ignore the fellowship that she feels towards the Beast. Beauty must learn that she is not bound by a cursed fate, but is free to choose the path that will bring her the most satisfaction. She must act selfishly and meet her own needs before she can return to her family and establish her position as a member of the community at Longchance.

\section{The Beast's Proposal and Beauty's Uncertainty}

Separated from her family, Beauty's choices are now her own, her budding relationship with the Beast requiring that she abandon the dismissive attitude that she holds towards her personal felicity and take responsibility for her future. In keeping with the original tale, every evening before Beauty retires for the night, the Beast asks, "Beauty, will you marry me?" (105). Beauty soon grows accustomed to the Beast's nightly proposal and is moved to consider the terms of her friendship with the Beast and her purpose in the palace. When the Beast first proposes, Beauty hesitates in her reply, "more in sadness than in fear," certain that her rejection will increase the Beast's desolation but unwilling to make a promise that she believes will bind her to the palace and prevent her from returning to her family (106). Misunderstanding Beauty's pause, the Beast assures her that the choice is her own, she can "Say yes or no without fear," no coercion or intimidation will follow (106). Accepting Beauty's response without question, the Beast allows Beauty to make her decision and realize the power that she holds over her future. 
Finding satisfaction in the easy camaraderie between herself and the Beast, Beauty promises to alleviate the Beast's isolation, a vow that results in an unexpected display of power as she alters her surroundings and changes the terms of the enchantment that keeps the Beast bound to his prison. Bothered by the silence resulting from the absence of living creatures in the palace, Beauty overcomes the force that repels wildlife from entering the grounds, drawing all manner of creatures to the otherwise barren location as her desire for life and sound increases. Unable to tend the rose garden that sustains him or effect any change of his own, the Beast is completely dependent on the force that guards the palace and, without control over the terms of his imprisonment, unable to seek aid for the sake of his roses. As Beauty later learns, the chance meeting between her father and the Beast, one in a series of similar encounters, is the only one to produce the desired effect-Beauty is the only one to take up her "fate" and join the Beast. It is Beauty, unassuming though she may be, who decides to travel to the Beast's palace, dictates the length of her stay, and settles on the reason why the Beast wants her. As powerful as the "Numen" that rules over the palace is, the strength of Beauty's character challenges the unnatural force that imprisons the Beast (192). Drawing on the same strength that aided her in the settlement of her father's estate, Beauty vows to repair the damage wrought to the garden during the Beast's seclusion. "There is something wrong here," she informs the Beast, "but we are putting it right, the roses and I.... Neither you nor the magic can tend it, but I can. It will not die. It will not. I will not let it" (151).

Questioning the power that she has over the palace, Beauty wonders if another can serve her purpose and produce the same result, as yet unaware that she chose her appointed task when she made her promise to the Beast. Comparing her situation to those 
found in "any nursery tale of magic," Beauty asks herself if "any maiden will do, anyany-monster, any hero, so long as they meet the right mysterious old women and discover the right haunted midnights," the particulars of her own experience irrelevant to the role that she has filled (192). Accepting that such knowledge lies beyond her comprehension, Beauty concludes, "I can only do what I can do... because I am the one who is here. $I$ am the one who is here," not because she satisfies the criteria for her role, but because she chose to be there (192). Taking on this mantle, Beauty starts to prepare for her later role as heroine when she rescues the Beast from his imprisonment. Only when Beauty realizes that she is not bound by the terms of a "curse", but can determine the course of her future, is she able to release the Beast from his physical confinement and return to Rose Cottage as a fully actualized individual with a purpose of her own.

\section{The End of the Corridor: Beauty Fulfils Her Destiny and Finds Her Place}

Imposing her will as she introduces animals and insects into the palace and its grounds and orders a stop to the constant shape-shifting that prevents the rooms in the palace from settling into a predictable pattern, Beauty expresses her desires without restriction, acting 'selfishly' and in defiance of the palace's keeper. Nevertheless, Beauty performs these actions under the auspices of her goal to alleviate the Beast's sadness, distancing herself from the pleasure that she derives in the process. It is during Beauty's fourth morning in the palace, after slipping into her role as gardener, that "her life in the Beast's palace... wrap[s] itself round her, [though] she [does] not notice it or how comfortably it fit[s] her" (166). Absorbed in her gardening, Beauty finds herself making plans for the garden's future, "by the end of this season, next year," foreseeing an extended stay among the Beast's roses despite her intention to return to Rose Cottage 
after the roses bloom (147). During her fourth day in the greenhouse, Beauty looks forward to the day when the roses will flourish, planning the garden paths that she will design as soon as the buds reveal their colors. At ease with the thought of remaining with the Beast, Beauty finds that "the implications of her words" no longer distress her (167). Instead, Beauty finds that, once a comfort, the thought of leaving after the roses bloom now distresses her more than the possibility of remaining away from her family. Confused by the direction of her thoughts, Beauty tells herself, "The roses will grow again, and then I will be able to go home.... frighten[ing] herself with the violence of her weeping" when this statement fails to console her as it once did (197).

Convinced that as the link between Rose Cottage and the Beast's enchanted palace, she is the sister who possesses the curse, Beauty relies on herself to unburden the Beast and her family. Experiencing a vision, Beauty observes a quarrel between her family and the local squire's eldest son; certain that her family is in danger, Beauty's urgency to come to her family's aid wins over her wish to "comfort the unhappy lost creature" that she now recognizes as the Beast (233). Moreover, it is also during this vision that Beauty learns of the history that connects Longchance's legendary curse and the enchantment that holds the Beast captive. As when she first learned of the legend concerning Rose Cottage, Beauty holds herself responsible for the conditions of the curse, "I must go away from this place," she tells the Beast, "If I carry this curse,... at least let me carry it away" (236). As she prepares to leave, Beauty finally comprehends that the power that holds the palace "can touch nothing living," and as the Beast has never had any power over her, so too has he "never been able to hold [her] against [her] will" $(136,237)$. Finding that she has the power to leave, Beauty acknowledges what she 
previously ignored; that she stayed with the Beast of her own accord and under no compulsion.

Although death awaits the Beast in Beauty's absence, the result of her failure to realize her promise, the Beast does not demand that Beauty remain and is regretful of the pretense that first drew Beauty to him (the false threat to her father's life that Beauty sought to prevent by her sacrifice). Agreeing that she should return to her family, the Beast believes that Beauty's loss is his reward for the lie that brought her to him. Believing that her duty in the palace is at an end now that the Beast's roses have flourished, Beauty is certain that "her first loyalty [must] lie" with her family (235). A "security" that she grabs hold of, the predictable familiarity of her family and their life at Rose Cottage promises her a release from the uncertainty of her feelings towards the Beast (235). However, returning to Rose Cottage, Beauty does not find the sense of ease that she expected to feel, too much of her new self is tied to her relationship with the Beast and is, thus, at odds inconsistent with her old life. As Beauty's enjoyment of the Beast's company was marred by her anxiety for her father and sisters, the experience of being in their company once more is spoiled by her anxiety for the Beast.

In order to restore the sense of rightness that she finds missing from Rose Cottage, Beauty must repair her fractured identity by acknowledging both of her personas, the Beauty of Rose Cottage and the Beauty of the Beast's palace. Her role as a gardener serves as the common factor between these two parts of her character. Beauty's request for the rose, her first "selfish" act, grants her the possibility of making her will known and deciding her 'fate'. Disregarding her role as gardener, Beauty underestimates her worth, devaluing her labor in the Beast's garden and her part in breaking the Numen's 
hold over the palace. Unlike Lionheart and Jeweltongue, whose names define their strong-willed personalities, Beauty must determine her own character. Though beautiful, Beauty feels limited by her appearance; her beauty "would fade.... She had always been the least of her sisters, called Beauty because she had no other, better characteristic to name her as herself" (249). Appreciating the character and talent displayed by her sisters, Beauty underestimates her own subtle strength and ability to stimulate and inspire those around her. As she revitalizes the dormant gardens at Rose Cottage, Beauty's support sustains her father and sisters when they are forced to move and start their lives anew, lifting them out of the depressed state that marked their final days in the city. Likewise, inspired by the loss of her own roses, Beauty's empathy for the Beast breaks through the barrier that holds him captive, averting the complete dissolution of the Beast's remaining humanity, the ultimate consequence of his isolation. It is not until Beauty recognizes the effect of her involvement in the lives of her loved ones that she can appreciate the strength of her own character and keep her unspoken promise to the Beast.

Allowing her sisters to support and advise her, Beauty learns to let others care for her and realizes what she denied while living in the Beast's palace, that in the Beast she found an equal and a partner. Like Beauty, the Beast is limited by his appearance, "He is very tall, and very wide, and very hairy; he is a Beast, just as he is named," she tells her sisters, but "that is not what he is like" (258). Coming to know the Beast as her companion, Beauty was able to see past his beastly form and manner, admiring the Beast's kindness and noble character. Because Beauty underestimated her worth as an individual, her rejection of the Beast's proposal is revealed as a consequence of her inability to rate herself as his equal. Asking herself why "someone so great and grand, 
like the Beast, [would] want to marry her," Beauty denies herself because she believes herself unworthy (249). Noting Beauty's distress as she tells them about her time spent in the Beast's company, Lionheart and Jeweltongue urge Beauty to consider why it is that she weeps at the thought of her separation from the Beast. When Beauty tells of the Beast's nightly proposal, Jeweltongue asks, "Well-and do you wish to marry him?" (255). Direct in her approach, Jeweltongue questions what it is about the Beast that Beauty objects to, if not his appearance. Disagreeing with Beauty's objection to the Beast's proposal, that "he is very great, and grand" and she is not, Jeweltongue finds that "it is perfectly obvious that she should say yes" (258).

Beauty returns to the palace under her own direction to claim her reward, happy to know that her sisters approve of her decision and do not reproach her for leaving so soon after her arrival. Thrust into the now-familiar scene that she encountered in her dreams, Beauty demonstrates the fortitude that was characteristic of her dream-self: "I seek for my Beast," she declares when she enters the palace, "I know him, and he is no monster" (264). Facing the palace's final trial, Beauty staunchly remains on course, resisting the Numen's efforts to delay her progress and prevent her from reaching the Beast. Certain of her intention, Beauty travels down the corridor "by her own will and of her own choice," each step "a victory for her" (266). Infuriating the Numen, Beauty chooses to blind herself and proceed without sight, finding that in the "darkness of her own choosing she could hug herself round with her own thoughts, her own being, her own knowledge of her self and of her existence" (266). Alone and under her own direction, Beauty's new sense of self is tried along with her conviction. Now certain of her merit, Beauty knows that she need not sacrifice her will any longer. Wanting to find 
the Beast, Beauty defies the path set before her by the Numen. Delayed from reaching her goal, Beauty tires of walking down countless corridors, leaving the path determined by the palace by throwing herself out of a window. In defiance of the Numen, Beauty chooses her own path to reach the Beast and alters the conditions of the curse to her advantage.

Completing her journey, Beauty tells the Beast that she will marry him and so breaks the curse, but the magic that binds the Beast grants Beauty a choice between two possible futures: she can choose a future of wealth and power alongside the handsome and influential man that the Beast once was, or she can choose the Beast that she knows and live quietly in Rose Cottage, possessing what she most desires-the company of the Beast and their roses. As the one presented with these two possibilities, Beauty determines her companion's future. Possessing absolute control over the Beast's future identity, this is the most 'selfish' decision that Beauty is called upon to make as she moves towards a fully actualized state of being. Counseled by the Beast's benign guardian, the greenwitch that raised her mother and left Rose Cottage to her family, Beauty is assured that choice, not chance, led her to the Beast, "Your Beast's heart came to you ... and no other ... because you are what you are" (280). Because she now knows herself and her mind, Beauty makes the choice that will bring her the most pleasure, a simple life at Rose Cottage with the Beast, the companion that she knows, not the "handsome stranger" that she is offered (286).

A healing force, Beauty's capacity for love and compassion is her own personal form of magic. Awaking in her old attic room at Rose Cottage after the ordeal, Beauty finds the Beast at her side, welcomed by her father and sisters, and named "Mr. Beast" in 
the absence of a more suitable title. With Beauty's return, the enchantment that held the Beast in thrall was dissolved and so the energies that were missing from Longchance are returned as well. As Beauty first learned when the villagers of Longchance discovered her ability to make the roses surrounding Rose Cottage grow, in this world of magic and enchantment, roses are rare because they require the greatest of elemental magics to thrive; as such, only powerful sorcery can force them to grow-force them, not encourage them-because these will only grow for the love and kindness of their caretaker. "There aren't many roses around anymore," Mrs. Greendown tells Beauty, "because they need more love than people have to give 'em, to make 'em flower, and the only thing that'll stand in for love is magic... And the bushes only started covering themselves with thorns when it got so it was only magic that ever made "em grow" (53). As Beauty and Beast are restored to Rose Cottage, the greenhouse that shelters the Beast's roses (the heart of the palace and the only area to escape the Numen's hold) is also restored to Rose Cottage, its presence, and that of the roses, signifying the restoration of the "magic" that was long missing from Longchance. The curse, as Beauty learns, was no curse at all, but "only a prediction of how... it [would] all be resolved" (228).

Taking her reward, Beauty successfully bridges the gap between her two worlds, creating a space that combines the heart of the Beast's palace and that of Rose Cottage. No longer torn between her two lives, Beauty now finds that Rose Cottage is the perfect place for her and the Beast, where they can share each other's company and remain part of the community. Moreover, with Beauty happily settled with the Beast, Lionheart, Jeweltongue, and their father are able to move on and establish lives of their own in 
Longchance. Because neither sister would leave Rose Cottage to marry while Beauty remained away, Beauty's return also signals a change in the family dynamic as the sisters are released from their prolonged wait and proceed with their weddings. Jeweltongue, who prefers town, weds the local baker and takes her father to live with her. Lionheart marries the squire's second son, who shares her love of horses. Beauty and Beast remain at Rose Cottage with their roses where "everything is exactly as it should be" (287). 


\section{Chapter IV}

\section{"Strange Life": Pride, Conceit, and Loss of Identity in Donna Jo Napoli's Beast}

Following Mesdames de Villeneuve and de Beaumont's standard, most retellings of "Beauty and the Beast," such as Beauty and Rose Daughter, present the tale from Beauty's perspective. The Beast's story, his past and the circumstances resulting in his transformation, are often left untold, the facts of the curse becoming known after Beauty releases him, or revealed in part during conversations between Beauty and the Beast. Concentrating on the Beast's untold story, Donna Jo Napoli's Beast is one of the few retellings presented from the Beast's perspective, and one of the only stories that explores the Beast's life before Beauty, particularly the psychological experience of living as a creature that is neither man nor animal.

Drawing on Charles Lamb's "Beauty and the Beast," Napoli presents the story of Lamb's Persian Prince Orasmyn; because Lamb's tale is one of the few that reveals the Beast's former identity and homeland, Napoli explores the implications of such a loss on the Beast's character, particularly his pride (Napoli 256). Napoli's retelling begins before the Beast's transformation, the result of a pari's curse (a pari is a kind of desert spirit or genie) in revenge for Orasmyn's prideful conceit, and follows him until he is restored to his human form. While Belle's involvement is essential to break the curse that holds Orasmyn in the body of a lion, it is more important that Orasmyn relinquish his pride. Too proud for his own good, Orasmyn rejects the support of others, overly confident in his intelligence and position as both prince and man. Once a self-possessed individual, Orasmyn's transformation compels him to reassess his notion of manhood, his experience as an outcast lion slowly disintegrating the pride that sustained his identity as Prince 
Orasmyn. As the Beast, Orasmyn comes to acknowledge and embrace his human weaknesses, learning compassion and trust from Belle and her pet fox, thus, breaking the curse that binds him in lion form.

Whereas Beauty and Rose Daughter concentrate on Honor and Beauty's journeys toward a more self-aware state of being, engendered by their involvement with their family and the Beast, Beast emphasizes the effects of isolation and displacement on Orasmyn's sense of self. In McKinley's retellings, the reward of "happily ever after" is acquired only after the heroine has recognized her worth as an individual. In Beauty, Honor must learn the value of honor and come to terms with her androgynous identity; while, in Rose Daughter, Beauty must become "selfish," voicing her desires and choosing her own path rather than suppress her wants for the sake of familial unity. The bonds established by Honor and Beauty aid their move towards individuation and restore them to the community as active, self-possessed individuals. However, as Orasmyn has a very well-developed sense of self before he is transformed into the Beast, his journey differs from those taken by Honor and Beauty. Intimately linked to his position as the Shah's son, Orasmyn's identity is determined by his understanding of himself as a Persian and Islamic male, his character born of the faith and tradition associated with these.

\section{The Error of Pride}

Cast into an unfamiliar body and banished from Persia, Orasmyn is forced to become completely self-reliant, a circumstance that necessitates a reevaluation of his concept of manhood and independence. Cursed by a vengeful pari, Orasmyn is transformed into a lion for knowingly permitting the sacrifice of a female camel that 
experienced pain during her lifetime, a dishonorable act prohibited by the rules governing the Islamic Feast of Sacrifices. Recently returned from a pilgrimage to Mecca, the Prince is to take part during the Feast for the first time. Averse to violence, Orasmyn prefers to read about the great feats of Persian heroes than engage in any act requiring bloodshed, including the annual sacrifice-one of the high holy days of Islam commemorating Ibrahim's willingness to sacrifice Ishmael (Napoli 6). Aware of Orasmyn's distate for violence, his mother advises him to seek another way to pay his respects to the Merciful One and partake in the preparations for the Feast, instead of engaging in the sacrificial rites. Obstinate, Orasmyn refuses his mother's suggestion and silently rejects her promise to send him her strength. Certain that "A prince should rely on no one," least of all a woman, Orasmyn holds himself to his own standard of princely conduct, tirelessly testing the strength of his will and relying on his own judgment (6). A lover of flowers, the "tender" Orasmyn prefers gardening and reading to hunting, his aversion to violence a perceived weakness that secretly shames him (6). Considering his mother's advice, Orasmyn admits that her suggestion is agreeable to him, "not every hajji must take part in the sacrifice... I am free to choose what duties I assume," he concludes (9). Therefore, Orasmyn decides that preparing the sacrificial camel shows his devotion to the Merciful One as well as partaking in the sacrifice itself.

Assisting the servant Kiyumars in preparing the she-camel for the sacrifice, Orasmyn is present when Kiyumars, who was responsible for selecting the Shah's offering, uncovers a wound hidden beneath the animal's pelt. Both men know that the scar that marks the animals back resulted from the removal of fat taken from its hump, a Persian custom forbidden by the teachings of Islam which decree that "Live animals are 
never to suffer at the hand of man" (10). As Kiyumars's superior and the son of the Shah, Orasmyn's judgment is tested by the incident. In the absence of another camel, the tainted camel is the only creature available for the royal family's sacrifice. Moreover, Orasmyn knows that because the error resulted from Kiyumars's oversight, the servant will be heavily punished. As a result, Orasmyn finds himself caught between his compassion for Kiyumars, and his desire to spare his family the shame of forgoing the sacrifice by failing to provide a camel for the Feast. Seeking a way out of his predicament, Orasmyn searches for a loophole that will render the camel fit for sacrifice. Admitting more knowledge of Persian folklore than Qur'anic verse, Orasmyn refuses to discuss the matter with one of the prayer leaders. As one of the most important days of the Islamic calendar, the Prince should be familiar with the regulation of the sacrifice. As a result, Orasmyn decides that, "Consultation would be a sign of weakness. The answer must lie within [him]," to seek advice is to reveal his own lack of knowledge and foresight in the matter (11).

Valuing the courage and intrepidness of the Persian heroes whose stories he treasures, Orasmyn seeks to cultivate these qualities and is convinced that these can only develop through complete self-reliance. As a result, Orasmyn believes it a sign of weakness for a prince to admit that he does not know how to resolve a problem. Pride, therefore, results in Orasmyn's downfall. His unwillingness to expose his weakness and reveal his insufficient knowledge lead him to conclude that, in the absence of an alternative, sacrificing the damaged creature is less dishonorable than forgoing the sacrifice. Insisting on settling the matter himself, Orasmyn proceeds as planned, helping 
Kiyumars hide the evidence of his mistake and guarding his secret as they lead the camel through the procession and observe the sacrifice.

Relying on the principles of "Discipline, self-restraint, [and] generosity" to strengthen his character and make him worthy of his future role as Shah, Orasmyn's pride suffers a terrible blow when he is cursed by the pari (21). Encountering the vengeful spirit, Orasmyn vindicates Kiyumars, claiming full responsibility for the sacrifice of the damaged animal. Holding Orasmyn responsible for this act, the pari reveals his tragic flaw, "You consulted no one," she says, "Prince that you are.... You were tested, Orasmyn. A royal test. And you failed" (29). Refusing to seek counsel, Orasmyn is a poor judge, unfit for momentous decision-making. Invoking the fourth of the five basic tenets of Islam, "Your actions will be rewarded or punished by divine justice," the pari curses Orasmyn: "Tomorrow your father will slay you, as you have slain the camel. Today you suffer that knowledge. You suffer, like the camel" (29).

The evolution of Orasmyn's conception of manhood begins with his transformation into a lion and the recognition that he will need to earn a woman's love if he is to find the means to regain his human body. A lion hunt having been planned for the day after the Feast, the pari transforms Orasmyn into the body of the male lion that the Shah determined to have as a trophy-kill. Apprehending the pari's cunning plan, Orasmyn realizes that submitting will only bring further grief to his father, who will discover his son in place of the dead lion. Choosing exile as a lion rather than remain within his father's reach, Orasmyn spares his father the pain that will ensue if the pari succeeds. "Proud, stupid Orasmyn," the pari calls him as she informs him that, "Only a 
woman's love can undo the curse," a daunting proposition for the too proud Orasmyn who holds discipline and self-reliance above compassion and love (52).

Triumphing over one aspect of the curse, Orasmyn survives his father's hunt, but he suffers a fate comparable to death, the complete annihilation of his former self, a physical and emotional loss that renders him an outsider among humans and lions alike. Both animal and man, Orasmyn experiences the instinctual yearnings of the body that he inhabits, his human restraint repulsed by the leonine desire to kill and mate with abandon. Once eager to prove his independence, Orasmyn now finds himself forced to lead the life of a hermit; rejected by other lions for his weakness, he is a lion without a pride. Unable to overcome the natural urges of his lion body, Orasmyn develops a mantra in hope of preserving the vestiges of his humanity: "I am Orasmyn," he repeats when he senses that the leonine instinct is struggling to surpass human conscience (59). "I am Orasmyn. I have a conscience and a soul. I am Orasmyn," he insists (66).

Entrusting his soul to the Merciful One, it is the firmness of Orasmyn's faith that saves him and allows him to bear the loneliness of his situation. Experiencing the unpredictability of his new life, Orasmyn finds that his new body "requires not thought, but surrender," his former discipline giving way to the physicality of being a lion (71). Compensating for his inability to restrain the lion side of his self, Orasmyn devotes himself to observing the $w u d h u$ (the cleansing ritual that precedes prayer) and saying his prayers before eating, a decision that he reaches after his first bloody meal (71). Collecting what is left of his self "within [his] strange new skin," Orasmyn considers himself victorious despite his exile, having triumphed over the pari by renouncing his 
home (85). Nevertheless, the loss of community that marks Orasmyn's life as a wanderer mars this victory.

\section{More than Lion - Orasmyn's Human Self and Language}

A unique feature of Napoli's Beast, Orasmyn, unlike the Beasts in most other works, cannot speak while under the pari's spell, the loss of speech further isolating Orasmyn from humanity and limiting his means of communication. In Beast, Orasmyn becomes a true beast, not the ambiguous half-man, half-animal creature described in other stories. Unlike these other Beasts, Orasmyn's appearance reveals no aspect of the human self that lies hidden within the dumb lion. In Madame de Villeneuve's tale, for instance, the Beast is rendered dull and ignorant by the curse, but he retains the power of speech, allowing him to interact with Beauty on a regular basis and pose his nightly proposal. As with most versions of the story, the pari's curse can only be broken by a woman's love, thus, Orasmyn's inability to speak effectively bars him from communicating with Beauty. As a scholar, Orasmyn treasured language, his knowledge of Persian folktales rivaling his knowledge of the Qur'an, but as a lion, language becomes that which he most craves, one of the few remaining connections to his human past.

Unwilling to give his self over to the lion, Orasmyn contends that so long as he can "think the thoughts of a man," he will be able to retain his humanity (94). Frightened of the thought that his human mind will succumb to animal instinct with time, Orasmyn sets himself a goal: before leaving Persia, he hides a copy of Gulistan, a Sufi text that his mother gave him on the day of the Feast, in the palace's park. The text, promising the comfort of Sufi wisdom, is to "await a self that can open it and drink it thirstily," a self that has reconciled the limitations of this new life with that of the past and found balance 
between human reason and animal desires (101). Following his decision to leave Persia, Orasmyn determines to travel to India, certain that he will not find a woman to break the terms of the spell, and reluctant to succumb to death so easily. "I choose my destiny," he tells himself, "I will go to India," and make the best of the life he was granted (96). Declaring, "I am lion. And I will die lion, for no human woman will ever love me," Orasmyn determines that he "can live... [a] lion's life" without regret for his lost self (96). Certain that he will find a place among the lions of India, Orasmyn momentarily glories in his triumph over the pari, who "cannot ruin this [life]" as she did the old (97).

However, though Orasmyn trusts in his ability to secure his future as a lion, his human self is too present, preventing him from establishing himself among wild lions. In Rose Daughter, it is the Beast's human awareness that disturbs Beauty most when first she meets him, the contrast between human and animal resulting in a combination that is too discordant and unsettling. Animals, likewise, turn from the Beast, disturbed by his strangeness. Orasmyn finds himself in a similar situation, the conscience and soul that he recognizes as the root of his human self remains much too present for communion to occur between him and the lion's of India. On the fringes of lion society, Orasmyn survives as a scavenger. A poor hunter, a remnant of his former distaste for violence, Orasmyn finds it difficult to satisfy his appetite with the small creatures that he is able to kill. Compensating for this deficiency, Orasmyn shadows a lion family, watching over the pride as he persists in his aim to learn how to live as a lion and make the best of his situation. Though he eats what remains after the pride has gorged, Orasmyn does not interact with the lions, but learns to experience himself as a lion by observing and imitating their habits. Social creatures, the lions live as a community, the dissimilarity 
between his own solitary existence and the codependence of the pride making Orasmyn long for the support that he spurned as a prince. Despite Orasmyn's initial conviction that the innate nobility of his character will allow him meet the challenges of his new life without assistance, his need for community grows. Realizing that his failure to assimilate into the pride results from his inability to communicate with his fellow lions, Orasmyn finds that, as he was unable to remain among humans, without language he cannot live among lions.

During the intermittent period before Orasmyn returns to Persia for Gulistan and proceeds to journey to France in search of roses, he uses prayer to preserve the knowledge of language that he associates with his human self. Disciplining his mind and body by observing the wudhu and praying, Orasmyn relies on his silent recitation of Qur'anic verse to remind him of the Merciful One's compassion and the possibility that his humanity might be restored on account of his continued faith. His faith allows him to strengthen his later friendship with Belle, providing him with a limited, but pure means of communication. In spite of Orasmyn's willful decision to live solely as a lion, too much of Orasmyn's identity as a prince remains in his personality. Though he insists, "I need nothing from my old life, I need no one," Orasmyn needs companionship most of all (124). When first venturing on his journey, Orasmyn realizes, "All of me longs for company, the comfort of community," a sentiment that is repeated as he realizes that his efforts to live as a lion have resulted in failure, his inability to join the pride marking him for life as an outsider (90). As such, Orasmyn concludes, "I am lion, and I am not lion.... I am doomed to loneliness" (125). Without human or leonine language to communicate, 
Orasmyn cannot enter either society; only through prayer can Orasmyn give voice to his concerns.

\section{Seeking a Place of His Own - Orasmyn's effort to make a new life in France}

It is when Orasmyn accepts that he will never fit the part of a lion, despite his effort to adopt leonine habits, that he begins his to experience himself as he is, and so commences his journey towards self-actualization. As the scholar prince, Orasmyn's human identity relied on his studies and nobility, as much as on his Persian and Islamic heritage. Arrogant and proud, Orasmyn experienced himself as a prince, a state that he held to be synonymous with self-reliance and aloofness. In the absence of companions, Orasmyn loses those factors that define him-self-reliance is his only means of survival, aloofness becomes irrelevant in his solitude. Having surrendered to life as a lion, Orasmyn, nevertheless, realizes that he cannot separate his new identity from the old. As a consequence, Orasmyn understands that life as a lion in India is as impossible as life as a lion in Persia. No longer Prince Orasmyn, Orasmyn finds himself without place in Persia, but his attempt to make a life for himself in India only reveals his inability to master his role as a lion, as a result, Orasmyn must establish a place for himself where he can exist as both lion and man.

It is in France that Orasmyn integrates both parts of his being, establishing himself as the half-man, half-beast creature common to other versions of the tale. Briefly passing through Persia before heading for France, Orasmyn returns for his copy of Gulistan, driven by his desire to reclaim the book that he hid before traveling towards India. Uncertain of the path that he will take, Orasmyn derives inspiration from the book. Meaning "Rose Garden," Gulistan puts Orasmyn in mind of the roses that he so treasured 
in his past life (131). Remembering a French man that he met once, Orasmyn recalls the man swearing that French roses were superior to any other. Believing this recollection to be a sign from the Merciful One, Orasmyn forges ahead, certain that France will receive him for his love of roses.

Taking Gulistan from its hiding place, Orasmyn essentially regains language and reasserts his human self. Exhibiting the same physical discipline that he demonstrates when forcing his lion body into the position for prayer, Orasmyn accustoms his lion's eyes to reading, seeking solace in the words of Saadi's Gulistan. During the two years journey from Persia to France, Orasmyn carries the text, protecting it from the elements, and finds that the text protects him as well. Taking more circuitous, but safer routes in his effort to keep the book from suffering any damage, Orasmyn finds that "this book saves [his] body, as well as [his] soul," those routes that would harm the book also proving injurious to Orasmyn's well-being (135). Whereas his lion's body naturally chooses to swim across rivers and channels, and travel through valleys rather than scale mountains, Orasmyn's dedication to his "heart's last remaining treasure" signals the beginning of his effort to find balance between lion and man (135). Certain of his knowledge and selfcontrol, the pari's curse showed Orasmyn the carnality suppressed by the rigidness of his morality and personal code of conduct. In the face of his loss, Orasmyn embraces this carnal side as he trains himself in the ways of the lion. Failing at this, Orasmyn finds that both his survival and the possibility of breaking the curse depend on the union of his body and soul.

The journey to France offers a new beginning, granting Orasmyn a space where he can know himself as Beast, rather than beast. Reaching France, Orasmyn claims a 
small, abandoned castle for his home, the woods around the building providing him with ample game to feed his body, and the castle's abandoned library supplying his equally insatiable hunger for language and communication. Fluent in various languages, Orasmyn continues to nourish his human soul through literature and prayer, "these books give me my only opportunity to keep language strong inside me," he concludes, "language, which is the human vehicle for prayer-[his] lifeline" (146). Learning that his new home is believed to be haunted, Orasmyn takes advantage of the local superstition, playing the part of phantom to guard his solitude until he chooses to reveal his presence.

Without regard for the woman that he plans to lure, Orasmyn considers the woman's love a reward for his struggles; she will love him for all that he has done in preparation for her arrival, and he will be free to take her as his prize. Thinking only of himself, Orasmyn's imagines his future bride as a subservient being, his desire for her based solely on the possibility of release. Having journeyed to France with the promise of roses, Orasmyn sets about planting a lush rose garden on the castle grounds, hopeful that the roses will attract the woman that will be able to break the curse. In most of the stories, the Beast is confined within an enchanted castle. The pari does not grant Orasmyn this luxury, the enchantment of the castle is of his own making, and holds a purpose. Creating a "magical world within the perimeter of brambles" that surround the castle, Orasmyn is certain that a pleasing setting will allow him to "lure a woman" into his domain (144-45). Self-serving, Orasmyn foresees a time when he will be able to "take [his] bride and return to the company of humans, to the community that is [his] birthright" (145). As a consequence, Orasmyn is unprepared to find that Belle challenges his idea of "woman;" and is thereby forced to reassess his intended plan and take Belle's will into account. 


\section{Becoming the Beast - Orasmyn's Split Identity}

As Orasmyn later learns, the condition of the curse requires more than the love of a woman, he must own his limitations and accept the support offered to him by Belle. Orasmyn must overcome his pride, humble himself and acknowledge his weaknesses in order to complete his emotional and physical transformation. Though Orasmyn appreciates the loneliness that stems from his enforced self-reliance, the result of his outcast state, Orasmyn's staunch belief in his ability to break the pari's curse without assistance impedes his initial effort to gain Belle's trust and hinders his actualization. Adopting a fox kit as a present for his guest, Orasmyn comes to understand codependence and forgiveness as he experiences himself in the company of the young fox Chou Chou and Belle.

Discovering an outsider has invaded his home, Orasmyn meets Belle's father, the first human with whom he has had direct contact since his exile began. Frightened, yet intrigued by the man's presence in his home, Orasmyn wishes nothing more than to speak with the stranger, "A discussion about anything, any little thing, man to man," to reassure himself of his ability to communicate and reason as more than an animal (154). Confronted with the limitations of his lion's voice, a "rumble...not fit for conversation," Orasmyn turns to writing to communicate his demands when he finds the man stealing roses from his garden (154). Alarmed at the lion's ability to write, the man debases himself before Orasmyn, begging the beast for mercy, though Orasmyn only wishes to converse with him. Addressed by the man as "My lord", Orasmyn is repulsed by his "false flattery," the product of the man's fear and ignorance (161). "Call me Beast," he orders, silently wanting the man to "realize that no true beast tends a rose garden" (161). 
Finding that his endeavor to make his intent known is futile, Orasmyn encourages the man's mistaken belief, "[he] has already given me license-for he believes I have power beyond a mortal;" as such, Orasmyn concludes that the man will satisfy the Beast for fear of retaliation, delivering Belle as a sacrifice to save himself and his family (163).

As he sets his plan into action, Orasmyn relies on the model of princely conduct that he prized before his transformation, an ideal of masculine independence that places him in a position of authority over those whom he perceives as his inferiors and grants him the power to impose his choices on others. Certain of his good intention, Orasmyn views his reception of the girl as an act of charity; she will be well cared for and pampered to the best of his ability, enough to make her forget the family that he severed her from without her consent. Taking on his new persona, Orasmyn as Beast prepares for Belle's arrival, stocking the larder with items that he steals from local farms under cover of night; treats that he hopes will please the girl and make her amenable to him. Though Orasmyn concentrates on the girl's comfort, certain the girl will love him with time, if only as a pet, his intentions towards her are purely selfish. Acting on the same mistaken sense of righteousness that he acted upon when he chose to prepare the damaged camel for the sacrifice, Orasmyn looks after his own interest. "My little girl," he calls her as he plans for her arrival (166). The girl is reduced to the status of a malleable possession, a being whose trust can be gained with the promise of treats and play. The child will free him if he succeeds; she will grow to be his wife if he has his way, and then he will return to claim his place as a prince.

Through his interaction with Belle and Chou Chou, Orasmyn examines the animal and human aspects of his identity and reconciles these with the man that he once was and 
the man that he wants to become. Domesticating the young fox, Orasmyn earns the creature's trust; relying on Orasmyn for its meals, the fox overcomes the natural urge to flee from the predatory lion. Thus, in the fox kit, Orasmyn finds the kind of easy submission and acceptance that he hopes to receive from the child that he demanded. Distressed when he discovers that the child he expected is a grown woman, Orasmyn finds that he is repulsed by his lion's instinct to identify Belle as meat, even as his human self finds comfort and familiarity in her appearance.

Having lived in the absence of human company for so long, Orasmyn remains unaware of the lion's hold over his human self until meeting Belle. Delaying his meeting with Belle, Orasmyn finds that in his absence the woman mistakes the fox for the terrible Beast of her father's description. Already brought low by the futility of his scheme, Orasmyn attacks the kit without restraint and, thus, introduces himself to Belle as a true beast. Taken aback by his own violence, Orasmyn finds that he has "behaved more terribly than [he] ever could have imagined... [he] behaved bestially," without reason and in defiance of his aim to earn Belle's trust through her pet (and be loved as a pet in turn) (197). Regretting his momentary savagery, Orasmyn condemns his own lack of control. Unable to communicate with the fox, Orasmyn expresses his regret as he tends to the injured creature. "The part of me that knows you as more than meat, the being that I was, that part is sorry," Orasmyn silently confesses (198). Though regretful, it is this breach in Orasmyn's self-discipline that reveals the extent of his animality.

Effectively awakening the Beast's human side, Belle's arrival initiates a change in Orasmyn's perception of himself, encouraging him towards a new mode of self-discipline that gives rise to a concern for the welfare of others, and allows him to overcome his 
pride. Whereas Belle's father made himself abject before the Beast, Belle sets herself as his equal. In Belle, Orasmyn finds a companion whom he cannot intimidate into subservience, one who acts according to her own will despite her confinement. Like her father, Belle regards the Beast as a sentient and reasonable creature, but does not believe him a supernatural being. She acknowledges his brute strength after their brutal introduction, but does not grant him absolute power over her, simply accepting him as the "Beast". Practical and honest, Belle is not moved by the mystery of the Beast's unusual abilities, but strives to establish an amiable relationship with him despite the threat that he presents. Though she refers to him as "Mon Ami," her friend, Belle knows the Beast to be the one who demanded her presence, but she does not give him power over her (201). Fighting the urge to inform Belle of his ordeal, Orasmyn realizes Belle must know him "as the lion [he] has become, not as the prince [he] once was," if he is to earn her love and find release (200).

Concealing the truth of his situation, Orasmyn tells Belle not to ask about his identity, but Belle interprets his command as an injunction against questions in general. As a result, the early relationship between these two is marked by distance and silence. Desirous of a companion with whom to communicate, Orasmyn, nevertheless, finds that writing provides him with a limited, inadequate mode of expression. Listening to the onesided conversations that Belle holds when playing with her fox, Orasmyn realizes how "famished [he had been] for spoken language" (203). Consequently, it is Orasmyn's yearning for language and conversation that draws him closer to Belle. 
Aeneas and Gulistan - Orasmyn's story and his effort to reclaim his lost self

Having experienced the turmoil of separation from his family, Orasmyn finds the ease with which Belle becomes accustomed to her situation at odds with his own experience. Since his displacement from home, Orasmyn found solace in the familiarity of his faith and the remembrance of his past as a Persian and a Muslim. Belle, he believes, "exists only as a creature of [the] moment: without either memories or hopes," expressing no discontent or desire to leave (203). Practical in her approach, Belle establishes herself as a kind of housekeeper, cleaning and preparing the game caught by Orasmyn, and playing with Chou Chou. Consequently, Orasmyn mistakes Belle's practicality for a sort of placid indifference, and so assumes that because she reveals no dissatisfaction, she will be unable to sympathize with him and so learn to regard him as more than her keeper. It is not until Orasmyn learns that Belle hides her disappointment, only expressing it in writing, that the silence and misunderstanding between these two is broken.

Locating the remnants of his self in his treasured Gulistan, Orasmyn sympathizes with Belle and, thus, finds the means to establish a true friendship with her. Finding Belle as she is writing in a book taken from the castle's library, Orasmyn understands that, like him, Belle's identity is not limited to her appearance. Mistaking the Beast's interest in her actions, Belle believes he means to deny her the book. Displaying an obstinacy that she had hitherto concealed, Belle responds angrily to the perceived threat. The writing contained in the borrowed book, she argues, "is all that's left of [her]" (205). Learning that Belle identifies herself with a book encourages Orasmyn. Offering Belle his Gulistan, Orasmyn tries to convey what he cannot tell her - the distance that he has 
traveled and the inner being concealed by the lion's body. Unfamiliar with Farsi, Belle gleans Orasmyn's intention when he gives her Gulistan, but cannot read the book in order to learn what he wants her to know. Not willing to pass this chance, Orasmyn presents Belle with the copy of the Aeneid that he read when he first arrived in the castle. Sympathizing with Aeneas's plight, Orasmyn compares his own ordeal to that experienced by Virgil's hero. As a result, he trusts that Belle will be able to understand the parallel between himself and Aeneas and learn what he cannot openly tell her.

Reading the Aeneid at Orasmyn's request, Belle humors Orasmyn, who identifies with the loss of home experienced by Aeneas and reveres the "nobility, honor, loyalty, [and] glory" demonstrated by his exploits. For Orasmyn, Aeneas represents the model of manhood that he so idolized as a prince, the independent, strong male who thrives on adventure. Belle, however, rebels and refuses to read a story that glorifies a war that leaves misery in its wake (210). For the second time, Belle displays a willfulness that challenges Orasmyn's notion of womanhood. Expecting docility and finding obstinacy, Orasmyn reconsiders his perception of the woman that he found merely practical and "almost uninteresting" when he first met her (211). Recalling his mother's distaste for the violent scenes that he found so thrilling to read, Orasmyn concludes that Belle, like his mother, "holds more complexity" than he assumed during his early observations (211). Having given way to her determination when she refused to let him see her journal, Orasmyn now seeks a compromise, "Skip war," he writes; his need for her to read the tale allowing him to set aside his stubborn pride (212). Acceding to his request, Belle reads on, but Orasmyn soon realizes that though Belle remains unaware of the story's 
significance. Dismayed, Orasmyn relinquishes his original scheme, to earn her trust and love in order to break the curse.

Failing in his effort to make Belle understand his situation, Orasmyn returns to the prideful self-reliance that marked his identity as prince; however, what seems a negative regression becomes a moment of change for Orasmyn. Taking Belle's friendship for granted, it is when Orasmyn rejects Belle that he begins to note the value of her company. As he once refused his mother's support, Orasmyn spurns Belle's attempts to feed him and help him perform tasks that he cannot manage with his lion's body. Not wanting to encourage the assumption that he is a tamed beast like the fox, Orasmyn assures himself, "I need no one's help. I am Prince Orasmyn" (236). Ignoring Belle, Orasmyn turns to prayer, "I am alone, but for the Merciful One," he convinces himself (238). Giving himself over to religious observance, Orasmyn relinquishes the strict hold that he keeps over his relationship with Belle. While assuring himself of his lonesome state, Orasmyn abandons the privacy that he once sought. Even as he seeks to disassociate himself from his human desire for companionship, Orasmyn inadvertently opens himself up to such an experience when he overlooks Belle's presence during his evening prayer. Always on guard during his prayers, Orasmyn never permitted Belle to join him and, therefore, assumed that his ritual had gone unobserved. As such, Orasmyn is surprised to learn that Belle has long been aware of this practice and sought to join him. Consequently, it is when Orasmyn believes himself truly bereft of company that he is able to welcome Belle's friendship, his self-imposed loneliness allowing him to appreciate Belle as a companion, not just a woman capable of breaking the pari's curse. 


\section{Relinquishing Pride - Becoming "Me"}

For Orasmyn, self-actualization and transformation only become possible when he acknowledges his weakness- that he needs support despite his desire to appear as a powerful and independent figure. Though love is the key to breaking the curse in Beast, Rose Daughter, and Beauty, the ideal of love portrayed in Beast is one based on companionship and mutuality. Belle and Orasmyn need each other, and through this need they learn to know themselves. Self-assured and proud, Prince Orasmyn professed a desire to help others, but this desire was bound with his conception of the conduct befitting a prince. When telling Kiyumars to proceed with the preparations for the sacrifice, Orasmyn does so for fear of appearing ignorant of the rules and regulations governing the sacrifice, information that a prince should know. When he makes the bargain with Belle's father, Orasmyn assures himself that he will meet all of her needs, but he does so in order to earn her trust and reestablish his role as Prince Orasmyn. As the Beast, Orasmyn exists in an in-between state, not just physically, but emotionally as well. In this state, Orasmyn clings to his past identity, calling himself Prince Orasmyn and refusing to give up the possibility to return to Persia with his bride. However, Orasmyn also begins to adapt to life as Beast while in Belle's company, willingly giving up the possibility to break the curse if Belle accompanies him. The Orasmyn that emerges from the lion is neither Prince Orasmyn nor Beast, "Me, I am me," he realizes when he sees his hands (255). Only after Orasmyn learns to forgive, trust, and love, does he succeed in overcoming his loneliness and breaking the curse. Becoming worthy of Belle's love after he admits his weakness, Orasmyn frees his self from the lion body. 
Signaling a change in Orasmyn's perception of himself in relation to others, Orasmyn, who never admits weakness, accepts Belle's offer to join him in prayer and feed him, not as a pet, but as a friend. Though he hesitates, "I want to tell her I am Prince of Persia. I want to say I need no help. I am not weak," Orasmyn puts aside his pride and finds the company that he has craved since leaving Persia (243). Belle insinuates herself into Orasmyn's daily life in a manner that was impossible while he remained aloof and commanded control of their limited interaction. Establishing "a delicate equilibrium" in their daily routine, Orasmyn and Belle share their time together, neither claiming power over the other (240). However, afraid to repel Belle with his carnality, Orasmyn continues to question whether her efforts to invite him into her life can succeed, "Can we be compassionately blended? Can we be family together?" (243).

Acknowledging his need for company and support, Orasmyn becomes conscious of the negative effects of pride and conceit; hence, an Orasmyn who considers the needs of others before his own replaces the selfish Orasmyn who sought only to satisfy himself. Thus, Orasmyn's true transformation begins with this change; before he is restored to his human form, Orasmyn becomes a being capable of compassion and trust. Letting Belle visit her family on the condition that she return to him within three weeks, Orasmyn occupies himself by preparing for her return. Anticipating Belle's needs, Orasmyn hunts game, plants fruit trees, and collects feathers for a new bed. Though his actions reflect the preparations that he engaged in when first awaiting her arrival, Orasmyn now completes these tasks with Belle's comfort in mind, no reward is expected for his good deed. Despairing when Belle fails to return after three weeks, Orasmyn reviews his actions: 
Once upon a time, what seems like another lifetime ago, I planned to lure a woman here so that she could love me and break the pari's spell. Now that plan doesn't matter at all. I would gladly remain lion forever, if only Belle would return. (252)

Companionship is the reward that Orasmyn seeks, having learned to value the support that he rejected in the past. Equating the ecstasy of his approaching death with the late realization of his need for the support provided by Belle's friendship, Orasmyn feels that he has been "annihilated" by his pride and conceit (252).

As he becomes conscious of the importance of community and support, Orasmyn also comes to understand the meaning of forgiveness. Learning to forgive and trust, Orasmyn is able to receive the love that the pari was certain he would never earn. Having restrained his violent urges after injuring Chou Chou, Orasmyn assumed that the fox, a mere animal without a human soul, forgot the incident that resulted in his limp. Concentrating on Belle's delay, Orasmyn is irritated by the little fox's attempts to draw him into play. Snarling at Chou Chou, Orasmyn notes the other creature's fear and so learns that the fox "does know that [he] attacked him...And he forgave [him]," the little fox's forgiveness further humbles Orasmyn who had never forgiven himself for the error that resulted in his imprisonment (252). "All pride flames and turns to ash," when Orasmyn learns that Belle has returned to him because, unlike the members of the family that she left, the Beast "need[s] her like no one ever has before" (255).

In both Beauty and Rose Daughter, the Beast spent so long in his enchanted form that he has lost all recollection of his human name; Orasmyn only spent a period of a few years as a lion, having been transformed in early adulthood, moreover, because he was so 
adamant about retaining his human identity, he remained well aware of his past self. However, when he is liberated from the spell, Orasmyn reemerges simply as "Me," his past self undone and transfigures by the disintegration of the pari's spell. This new person retains the experiences of the prince, the lion, and the Beast, but has also transcended these roles. Orasmyn's reward is not the return of his human body, but forgiveness; as the Merciful One has shown him forgiveness for the taboo that he committed, Chou Chou has forgiven him for his misdeed, and Belle has shown him forgiveness for separating her from her family. Accepting forgiveness, Orasmyn has learned to forgive his own weaknesses, admitting his need for Belle's support and so finding in her the company and solace that he rejected when refused to receive the support of another.

Moreover, learning to feel compassion and empathetic towards Belle, Orasmyn perceives the error of his decision to use her to break the enchantment, gaining insight into the terms of the pari's curse and finding the ability to love unconditionally. Finding the means to change, Orasmyn reevaluates his concept of manhood and, in turn, princehood. Reflecting on the bargain that he struck with the merchant, Orasmyn admits, "The pari trapped me, and I trapped you .... A prince should know how to make better choices" (224). Engaging in a more compassionate manner of living after he accepts Belle and Chou Chou as family, Orasmyn begins to surrender his pride and finds the capacity to love. Forgiveness, compassion, love, these are the qualities Orasmyn needed to learn to become human. 


\section{Chapter V: Conclusion}

\section{The Hero's Journey}

In my analysis of McKinley and Napoli's retellings, I have focused on the evolution of the protagonist's conception of identity and self-hood. However, as part of the "Beauty and the Beast" tradition, these three novels can also be read as fairy tales. As such, I will examine how the concept of the hero's journey informs a reading of these retellings as fairy tales.

The hero's journey, as outlined by Joseph Campbell in The Hero with a Thousand Faces, can best be described as the cycle of events that shapes the hero's persona. Traditionally, the hero is male; however, I find that both Honour and Beauty challenge the notion of the male hero, serving a double-role that permits them to act as both hero and lady in their respective journeys. Orasmyn, as the Beast, serves the role of hero as well, but his is an inward journey as much as an outward adventure, rescuing himself in the process. For the hero, the adventure becomes an act of self-discovery, commencing when the hero answers the summons that removes him or her from that which is familiar and secure. The hero is "transfigured" by this process, emerging as a new person possessed of some sacred knowledge (Campbell 20).

The hero's journey follows a pattern of "separation," "initiation," and "return" (30). This process begins with the "Call to Adventure," the summons that first draws the hero into the cycle of transformation and which must be answered if the hero is to succeed; to deny the call is to remain in an immature state without purpose (23). Separation ensues when the hero answers the call, and thereby encounters the unknown and engages in a process of personal transformation. Initiation refers to the series of trials 
that the hero undergoes on this journey, those which must be passed before the hero can attain the "Ultimate Boon," the reward at the end of the journey. The final step in the hero's journey is the return to the community; as the hero is reintroduced to the community, the knowledge acquired during the adventure has a revitalizing effect on the community at large.

\section{Honour: The Lady-Knight}

The process of initiation and transformation through which Honour becomes aware of her role as lady-knight in Beauty follows the archetypal pattern of the hero's journey. For Honour, the true call to adventure arrives when her father returns with the rose and the Beast's summons. Honour is presented with an option: she may answer the summons and journey to the Beast's palace, or she may reject the call and permit her father to meet an unknown fate. Honour's "Call to Adventure" is a matter of responsibility; because she requested the rose seeds that lead her father to take the rose, she feels it is her duty to make amends. Deciding that, at eighteen, she is "ready for an adventure," Honour accepts the summons, embracing the possibility for change signaled by her removal from the familiar comfort of home (McKinley 78).

Traditionally, the male hero's journey involves a series of trials and voyages, each testing the hero's mettle before he can receive his boon. Honour's journey is restricted by her sex; hers is not a journey to distant lands, but a journey of a few miles. Honour's first journey takes her from the city to the country, and prepares her for the separation that will mark her journey to the Beast's palace. Additionally, Honour's is not an exile or a removal from society on a grand scale, but a removal from the family home. While de Beaumont's story emphasizes the marriage plot, McKinley's story adapts the notion of 
women's separation from the family through marriage. Honour leaves her family and finds a partner; but more than love, her prize is the personal transformation effected by her newfound awareness of her self.

A feature of Beauty, Rose Daughter, and Beast, the main trial in each story is the protagonist's struggle to establish identity. As such, Honour's trial is not marked by a series of conventionally heroic deeds. Instead, Honour's initiation begins with her introduction to the Beast, who challenges her low self-regard and, thereby, presents her with the task that she must endure-uncovering the meaning of honor and learning to see herself as a worthy individual. Honour's growing self-awareness is also marked by a series of events that encourage the transformation that is completed when she releases the Beast. The first of these is her victory over Greatheart and the Beast. Her success reveals the power that she holds, as well as the trust and respect she has earned from both her host and her horse. Honour's second trial transforms her. Aware of the confining atmosphere of the palace, Honour is overcome by a sense of entrapment that terrifies her when she realizes the implications of living the kind of solitary life that the Beast has experienced for two centuries. The timeless quality of the palace changes Honour's perception of herself; suddenly she is aware the insignificance of her position as a spectator. However, Honour mistakes her role; she revolts against the possibility of remaining trapped within the palace for an eternity alongside the Beast and soon after asks to return to her family for a short stay.

While the Beast's rose initiates the series of events that result in Honour's separation from her family, it is the Beast's marriage proposal that acts as a catalyst for Honour's transformation. The proposal is the key to the Beast's release, but it is also the 
key to Honor's transformation. The Beast is bound until Honour accepts his proposal; in turn, Honour is bound to her quest. The anxiety that plagues Honour during her visit to her family makes her realize that she has yet to complete her task. Honour becomes the lady-knight when she charges forth to the Beast's palace. In the absence of a villainous force to deny Honour her reward, she is forced to break past the seemingly insurmountable barriers that she set for herself-her lack of confidence and low selfesteem. Thus, the knowledge that Honour gains during her final trial is not a universal truth, but a personal one; she overcomes her dissatisfaction when she looks in the mirror and finds herself worthy of her reward.

Honor's return and her union with the Beast re-establishes the long-forgotten family line attached to the palace, the bounty resulting from their union fructifying the community to which they are both restored.

\section{Beauty: The Unlikely Heroine}

Starting her quest in much the same way as Honour, Beauty's journey begins with the Beast's summons; however, while Honour must confront her feelings of inadequacy and low self-worth, Beauty's character is challenged by the sinister force that controls the Beast's palace. The Numen that holds the Beast's palace effectively alters Beauty's perception of herself and her surroundings, awakening her dormant character and drawing out the ceaseless determination that marks her as a hero. Beauty's separation from her family draws her away from the security of Rose Cottage into the alternate reality of the palace. Unlike Honour, who spends months with the Beast before accepting the part that she must play in releasing him from the curse, Beauty has seven days to understand her purpose. 
Though the rose is a recurring motif in the "Beauty and the Beast" tradition, roses are especially significant in Rose Daughter, representing Beauty's determination and willfulness, the source of the magic that holds the Beast, and the heart of the Beast himself. When Beauty first receives the Beast's rose, she plants cuttings in the garden at Rose Cottage, establishing a connection between her ordinary home and the fantastical realm of the palace. Though Beauty first becomes "selfish" when she discovers her passion for gardening, and roses in particular, her transformation truly begins when she tends the Beast's roses. The one part of the palace that exists beyond the control of the Numen, the magic of the rose garden can only be touched by Beauty, her power to effect change as she revives the dying plants and welcomes life back into the palace signaling the start of her emergence as a heroine.

Magic permeates the world of Rose Daughter, as such, Beauty is ultimately transfigured by the knowledge that she gains after she challenges the numinous force that rules the palace. While Honour charges through the forest on her steed to rescue the Beast, Beauty can only return to the palace by becoming part of it. When Beauty travels to Rose Cottage and acknowledges her desire to join the Beast, she is startled to find that despite her wish to return, she is unable to do so; Beauty is no longer welcomed by the Numen. As a consequence, the path that first lead her to the palace is now hidden from her. Understanding that she must find another way to return to the Beast, Beauty searches for the cuttings that she planted, the remnants of the rose that initiated her journey. Placing one of the petals in her mouth, Beauty absorbs the elemental magic that touches the garden, the power that keeps the Numen at bay. 
In the palace, Beauty is met by the god-like Numen, it is this force that Beauty must defy and overcome if she is to receive her boon. As the Beast was punished for daring to seek forbidden truths, so Beauty now faces the source of these truths. While the Beast was found wanting, unworthy of the knowledge that he uncovered, Beauty emerges from her confrontation with the Numen, rewarded for her steadfast dedication and selfpossession. Earning her reward, Beauty's triumph restores the magic that was missing from the town of Longchance, thus, the community receives the reward of Beauty's triumph.

\section{Orasmyn: The Cursed Hero}

Whereas Honour and Beauty must act the part of hero and save the Beast, Orasmyn must save himself. Orasmyn's journey begins with a choice; he is presented with a dilemma (the question of the tainted camel) and makes the wrong decision in his haste to avoid embarrassment for himself. Cursed for his error, Orasmyn can choose to remain in Persia and satisfy the pari's desire for vengeance, to die at his father's hands, or leave his homeland for an alien existence as a lion. Choosing the latter, Orasmyn's travels take him across Asia and Europe, separating him from all that is familiar. While Beauty and Honour leave their homes, they each remain hopeful that they will be able to visit their families - they are also only a short distance from their homes. Though Orasmyn dreams of returning to Persia if he succeeds in breaking the spell, he remains aware of the unlikelihood of a reunion with his family. The transformation also results in a separation of body and self that necessitates Orasmyn's reevaluation of his human self.

While the Beasts of Rose Daughter and Beauty are confined within their palaces until their savior arrives, Orasmyn is spurred on an adventure, becoming more than a 
mere victim. Orasmyn needs Belle, but the Beauty and Beast dynamic established between these two differs from that between Beauty and Honour and their partners. Orasmyn learns from Belle, understanding the nature of compassion, love, and forgiveness while in her company - the Merciful's One's teaching-but ultimately saves himself. As a hero, Orasmyn is unlike Beauty and Honour, for he engages in an epic journey to understand the lessons of the Merciful One, certain that only his faith can save him from the curse, but his trial is purely personal-he is the victim of his own error. Free to roam, but trapped within the lion's body, Orasmyn's knowledge is gained through introspection and prayer, a learning experience that culminates in the death ecstasy that he experiences before Belle revives him. Though Orasmyn is not immediately restored to the community from which he was exiled, his adventure ends with the promise of family as he and Belle become "compassionately blended" (Napoli 243).

\section{The Hero's Return}

Though Honour, Beauty, and Orasmyn encounter distinctly different trials while on their individual journeys, encouraging them to examine their self-perception and attain self-actualization, the outcome of each of these three journeys has a similar effect-the hero's return has a revitalizing effect on the community to which they are restored.

Seeing herself as a queen-like figure, Honour finds that the success of her endeavor restored the Beast's palace Blue Hill. Once taboo, the wood where the Beast's palace lay hidden is no longer the forbidding area feared by the residents of Blue Hill, but a welcoming stretch of forest. The citizens of Blue Hill parade down the path leading to the palace, welcoming Honour and Beast and joining them in their splendor. A sense of prosperity and fruitfulness mark Honour's return. 
Beauty's return signals more than the completion of her journey, it creates the means for her family to become true members of the community at Longchance. Though Beauty's father and sisters are accepted by the citizens of Longchance, Beauty's absence inhibits their ability to feel a part of the community. The fear that Beauty's whereabouts might become known, and result in their expulsion from Longchance, taints the relationships that Beauty's father and sisters wish to establish. As such, when Beauty returns, her father and sisters are able to leave Rose Cottage, finding partners and positions within the community, while Beauty tends to the magic that she restored.

Oramsyn's return, on the other hand, differs from that of Honour and Beauty; his is a rebirth with the promise of regeneration. In Lamb's version of the story, the Beast is restored to his position as Prince Orasmyn after the spell is broken and intends to travel to Persia with his bride. In contrast, Napoli's Orasmyn does not indicate any intention to return to Persia; instead, he and Belle "bow to the Merciful One and make a pool [with their] tears in the middle of [the] garden" that Orasmyn first created when he decided to create a paradise around the abandoned castle (Napoli 255). Like Beauty and Beast in Rose Daughter, the image of the garden is associated with the union between Orasmyn and Belle; together these two will bring life back to what was once a desolate area. 


\section{BIBLIOGRAPHY}

Accardo, Pasquale. The Metamorphosis of Apuleius: Cupid and Psyche, Beauty and the Beast, King Kong. Madison: Fairleigh Dickinson UP, 2002.

Altmann, Anna E., and Gail De Vos. Tales, Then and Now: More Folktales as Literary Fiction for Young Adults. Englewood: Libraries Unlimited, 2001.

Ashliman, D.L. Folk and Fairy Tales: A Handbook. Connecticut: Greenwood, 2004.

Beaumont, Jeanne-Marie Leprince de. "Beauty and the Beast." Beauties, Beasts, and Enchantment: Classic French Fairy Tales. Trans. Jack Zipes. New York: Meridian, 1989.

Campbell, Joseph, ed. The Portable Jung. New York: Penguin, 1971.

---. The Hero with a Thousand Faces. Princeton: Princeton UP, 1968.

Fairy Tales and Society: Illusion, Allusion, and Paradigm. Ed. Ruth B. Bottigheimer. Philadelphia: Pennsylvania UP, 1986.

Franz, Marie Louise von. Individuation in Fairy Tales. Boston : Shambhala, 1990.

Griswold, Jerry. The Meanings of "Beauty and the Beast": A Handbook. New York: Broadview, 2004.

Guerin, Wilfred L., et al. A Handbook of Critical Approaches to Literature. New York: HarperCollins, 1979.

Hearne, Betsy. Beauty and the Beast: Visions and Revisions of an Old Tale. Chicago: Chicago UP, 1989.

Jung, C.G. The Archetypes and the Collective Unconscious. The Collected Works of C.G. Jung. Vol. 9, Part 1. Trans. R.F.C. Hull. Ed. Herbert Read, Michael Fordham, Gerhard Adler, William McGuire. New York: Bollingen, 1968.

McKinley, Robin. Beauty: A Retelling of the Story of Beauty \& the Beast. New York: HarperCollins, 1978.

---. Rose Daughter. New York: Ace, 1997.

Napoli, Donna Jo. Beast. New York: Simon Pulse, 2000.

Sackelman, Ellen R. "More than Skin Deep: Robin McKinley's Beauty: A Retelling of the Story of Beauty and the Beast." Women in Literature: Reading through the 
Lens of Gender. Ed. Jerilyn Fisher, and Ellen S. Silber. Westport: Greenwood, 2003.

Storr, Anthony, comp. The Essential Jung: Selected Writings. Princeton: Princeton UP, 1983.

Tatar, Maria, ed. The Classic Fairy Tales. New York: Norton, 1999.

Villeneuve, Gabrielle Suzanne de. "The Story of Beauty and the Beast." Beauties, Beasts, and Enchantment: Classic French Fairy Tales. Trans. Jack Zipes. New York: Meridian, 1989.

Zipes, Jack. "Jeanne-Marie Leprince de Beaumont." Introduction. "Beauty and the Beast." By Jeanne-Marie Leprince de Beaumont. Beauties, Beasts, and Enchantment: Classic French Fairy Tales. Trans. Zipes. New York: Meridian, 1989. 